\title{
Secondary Organic Aerosol Formation of Fleet Vehicle Emissions in China: Potential Seasonality of Spatial Distributions
}

Keren Liao, ${ }^{1}$ Qi Chen, ${ }^{* 1}$ Ying Liu,,${ }^{1}$ Yong Jie Li, ${ }^{2}$ Andrew T. Lambe, ${ }^{3}$ Tong Zhu, ${ }^{1}$ Ru-Jin Huang, ${ }^{4}$ Yan Zheng, ${ }^{1}$ Xi Cheng, ${ }^{1}$ Ruqian Miao, ${ }^{1}$ Guancong Huang, ${ }^{1}$ Reza Bashiri Khuzestani, ${ }^{1}$ Tianjiao Jia ${ }^{1}$

${ }^{1}$ State Key Joint Laboratory of Environmental Simulation and Pollution Control, BIC-ESAT and IJRC, College of Environmental Sciences and Engineering, Peking University, Beijing 100871, China

${ }^{2}$ Department of Civil and Environmental Engineering, Faculty of Science and Technology, University of Macau, Taipa, Macau, China

${ }^{3}$ Aerodyne Research, Inc., Billerica, Massachusetts 01821, United States

${ }^{4}$ State Key Laboratory of Loess and Quaternary Geology, Center for Excellence in

Quaternary Science and Global Change, and Key Laboratory of Aerosol Chemistry \& Physics, Institute of Earth Environment, Chinese Academy of Sciences, Xi'an 710075, China

*Correspondence to:

Qi Chen (Email: qichenpku@pku.edu.cn)

This file includes:

Supporting text

Supporting Table S1-S5

Supporting Figure S1-S17

Supporting references 
Number of pages: 39 


\section{Section 1. Sampling locations}

Figure S1 shows the mapping of the sampling locations. The $4^{\text {th }}$ Ring Road of Beijing is a busy traffic road with over $90 \%$ of the fleet made up of light-duty gasoline vehicles (LDGVs) and has less traffic jam ( $\sim 4000$ vehicles per hour) than inner ring roads between 9:30-16:00 when the PKU mobile laboratory sampling on-roads in this study. Datunlu Tunnel is located by the south of Beijing Olympic Forest Park. It is less busy ( $\sim 1000$ vehicles per hour) than the $4^{\text {th }}$ Ring Road during the daytime. Besides, this tunnel is not as long as the one in Pittsburgh ${ }^{1}$ and has ventilation port every hundred meters. Therefore, it is supposed to be less influenced by vehicle emissions than the on-road site. The roadside site is by the roadside of $4^{\text {th }}$ Ring Auxiliary Road near Zhongguancun Bridge 2. For traffic volume and the distance to the road center, we suppose the roadside air in this study was more diluted by ambient air than the onroad air.

\section{Section 2. Measurement details}

\section{S2.1 Proton Transfer Reaction-Quadrupole interface Time-of-Flight Mass Spectrometer}

\section{(PTR-QiTOF)}

Volatile organic compounds (VOCs) were real-time measured by PTR-QiTOF, which ionized a fraction of VOCs in proton-transfer reactions with hydronium ions $\left(\mathrm{H}_{3} \mathrm{O}^{+}\right)$. The PTRQiTOF was operated at $3.8 \mathrm{mbar}(\mathrm{E} / \mathrm{N}=120 \mathrm{Td})$ for the drift tube with the temperature of $85^{\circ} \mathrm{C}$ to reach a sensitivity of $850-4350 \mathrm{ncps} \mathrm{ppb}^{-1}$ and mass resolution $(\sim 4000 \mathrm{~m} / \Delta \mathrm{m})$ during the mobile measurements. Mass spectra were collected at the time resolution of $2 \mathrm{~s}$. Ambient air was sampled through a 2-m, 1/4 inch (O.D.) Teflon tube with a flow rate of $1.3 \mathrm{~L} \mathrm{~min}^{-1}$. Calibrations were conducted before and after the whole campaign. The PTR-QiTOF 
background at each mass was determined by humidified zero air before the measurements. Aromatics, carbonyls, alcohols, and terpenes were calibrated using gas standards (Spectra Gases, $\sim 1 \mathrm{ppm}$ ) at five concentration levels from 0.5 to $20 \mathrm{ppb}$. For uncalibrated species, the quantification was based on the established transmission curve described previously by Huang et al. ${ }^{2}$ The species and the corresponding reaction rate $(k)$ measured by PTR-QiTOF are provided in Table S2. ${ }^{3}$ The uncertainty was less than $20 \%$ for all of the calibrated species with standards. The range of detection limits (3×signal/noise) for the species in Table S2 was 3-190 ppt with an average of $40 \mathrm{ppt}$. From the previous examinations of the Teflon tubing length to the loss of organic compounds, ${ }^{2}$ the wall losses were estimated to be $5 \%$ for most VOCs, and $5-25 \%$ for IVOCs under our experimental settings. We applied a factor of $20 \%$ to correct the wall loss effect of selected IVOCs in this study. There might be a higher loss for highly oxygenated species like acids, but they are not generally regarded as important SOA precursors, so we ignored this in our analysis.

\section{S2.2 Time-of-Flight Aerosol Chemical Speciation Monitor (TOF-ACSM)}

The chemical composition of non-refractory $\mathrm{PM}_{2.5}$ (i.e., ammonium, nitrate, sulfate, chloride, and organic compounds) was measured by TOF-ACSM. This instrument was equipped with $\mathrm{PM}_{2.5}$ aerodynamic lens and a capture vaporizer. The instrument setup has been described previously. ${ }^{4}$ The TOF-ACSM data have 40 -s time resolution and were processed in Tofware (Tofwerk version 2.5.13). A collection efficiency of 1 was applied. Calibrations of ionization efficiency (IE) and relative IE of the TOF-ACSM followed the standard procedures by using $350 \mathrm{~nm}$ pure $\mathrm{NH}_{4} \mathrm{NO}_{3}$ and $\left(\mathrm{NH}_{4}\right)_{2} \mathrm{SO}_{4}$.

PMF analysis was conducted on the organic mass spectra by using the Igor PMF evaluation 
tool (PET, version 3.00B) follow the same procedure as described by Zheng et al. ${ }^{4}$ The unitmass-resolution (UMR) data between m/z 12 and 200 are used in the PMF analysis. Six factors were tested in the PMF runs with various rotational parameter $\left(f_{\text {peak }}\right)$ values (i.e., -1 to 1 , stepped by 0.2 ) and the seed number of 0 . The choice of 5 factors for this study was first determined by the ratio of $Q$ to $Q_{\exp }$ (i.e., the sum of the squares of the uncertainty-weighted residuals to the expected values) (Figure S15). The ratio decreased by 14\%, 19\%, 7\%, and 2\% (of the maximum $Q$ ) when the factor number $(p)$ increasing from 2 to 6 . Four or more factors are needed to account for the majority of the data variance. The residual was $1-2 \%$ for $p=3,4$ and $<0.5 \%$ for $p=5$ and structure in the residual was significantly reduced by increasing from $p$ of 4 to 5 (Figure S15). The 5-factor PMF solutions at $f_{\text {peak }}$ other than -0.8 were converged, and they were comparable. Therefore, a 5 -factor solution at $f_{\text {peak }}$ of -0.4 was determined in this study.

\section{S2.3 Oxidation Flow Reactor (OFR)}

On-road air was oxidized in a Potential Aerosol Mass OFR to produce OVOCs and SOA from the $\mathrm{OH}$ oxidation of gas phase precursors. The reactor is an aluminum cylinder with an internal volume of $13.3 \mathrm{~L}$. With a total instrument flow rate of about $4.5 \mathrm{~L} \mathrm{~min}^{-1}$, the calculated average residence time is about $177.3 \mathrm{~s}$. Four UV lamps emitting light at 185 and $254 \mathrm{~nm}$ were used in the reactor. Under $185 \mathrm{~nm} \mathrm{UV}$ light, $\mathrm{OH}$ and $\mathrm{HO}_{2}$ radicals are generated directly in the reactor from $\mathrm{H}_{2} \mathrm{O}$ photolysis, and $\mathrm{O}_{3}$ is also produced due to $\mathrm{O}_{2}$ photolysis. Under $254 \mathrm{~nm} \mathrm{UV}$ light, the photolysis of $\mathrm{O}_{3}$ produces additional $\mathrm{OH}$ by the reactions of $\mathrm{O}_{3} \stackrel{254 \mathrm{~nm} h v}{\longrightarrow} \mathrm{O}_{2}+\mathrm{O}\left({ }^{1} \mathrm{D}\right)$ and $\mathrm{O}\left({ }^{1} \mathrm{D}\right)+\mathrm{H}_{2} \mathrm{O} \rightarrow 2 \mathrm{OH}$ A quasi-ambient temperature and relative humidity $(\mathrm{RH})$ with the variations less than $5{ }^{\circ} \mathrm{C}$ and $10 \%$ was achieved. The range of $\mathrm{H}_{2} \mathrm{O}$ mixing ratios was 0.15 - 
$0.6 \%$, corresponding to $25-80 \%$ of $\mathrm{RH}$ at $283 \mathrm{~K}$. NO is produced in the OFR via the reaction $\mathrm{O}\left({ }^{1} \mathrm{D}\right)+\mathrm{N}_{2} \mathrm{O} \rightarrow 2 \mathrm{NO}$; here, $\mathrm{N}_{2} \mathrm{O}$ with a volume mixing ratio of $4.2 \%$, was injected at the OFR inlet. The photon fluxes of the lamps are determined based on the off-line calibrations of $\mathrm{SO}_{2}$

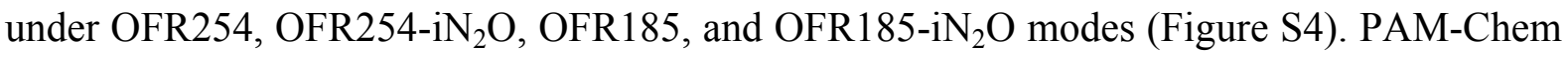
model was used to estimate the $\mathrm{NO}: \mathrm{HO}_{2}$ ratios under ambient conditions of pollutant concentrations and meteorological conditions. We used the irradiance measured for $254 \mathrm{~nm}$ as a reference for ambient conditions to adjust the photon fluxes for the model. The estimated NO: $\mathrm{HO}_{2}$ ratios ranged from about 2 to 10 .

$\mathrm{OH}$ exposure was estimated from the real-time decay of the ambient species (i.e. benzene and toluene) monitored by PTR-QiTOF. ${ }^{5-7}$ This method is most accurate when the consumed fractions of the tracer species are within $10-90 \%$. A $10-90 \%$ fraction remaining of benzene $\left(k_{\mathrm{OH}+\text { benzene }}=1.22 \times 10^{-13} \mathrm{~cm}^{3}\right.$ molecules $\left.{ }^{-1} \mathrm{~s}^{-1}\right)$ can be used for estimating $\mathrm{OH}$ exposure between $8.6 \times 10^{10}$ and $1.9 \times 10^{12}$ molecules $\mathrm{cm}^{-3} \mathrm{~s}$ (i.e. 0.7-14.6 days assuming average atmospheric concentration of $\mathrm{OH}$ radical of $1.5 \times 10^{6}$ molecules $\left.\mathrm{cm}^{-3}{ }^{8}\right)$ and toluene $\left(k_{\mathrm{OH}+\text { toluene }}=5.63 \times 10^{-}\right.$ ${ }^{12} \mathrm{~cm}^{3}$ molecules $^{-1} \mathrm{~s}^{-1}$ ) for $\mathrm{OH}$ exposure between $1.9 \times 10^{10}$ and $4.1 \times 10^{11}$ molecules $\mathrm{cm}^{-3} \mathrm{~s}$ (i.e. 0.2-4.7 days). ${ }^{9}$ The final $\mathrm{OH}$ exposure was the average value of $\mathrm{OH}$ exposure calculated from benzene and toluene. In this study, around $10 \%$ of the data beyond this $10-90 \%$ range was removed out of large uncertainties.

To evaluate the particle and vapor losses in the reactor, we compared the concentrations out of the reactor line with those measured through the bypass line when UV lights are turned off. Standard gas cylinder of mixed VOCs was used for evaluating volatile compounds. The concentrations of the 17 VOCs in both lines were similar under conditions of low-, medium-, 
and high- humidity, indicating minimal losses of volatile gases (Figure S5a). Particle losses were about $10 \%$ on the basis of the comparison between the reactor and the bypass lines under typical ambient non-haze conditions (Figure S5b) and have been corrected in the data.

For low-volatility organic compounds (LVOCs), there are other fates including condensational loss to the walls of the reactor, further reaction with $\mathrm{OH}$ to produce either condensable or non-condensable gas-phase products, and exiting the reactor in the gas phase competing with condensation onto aerosols. ${ }^{10}$ We conducted the fate analysis of LVOCs following the method of Palm et al. ${ }^{10}$ We used the aerosol number and mass size distribution measured at the PKU roof site in winter 2017 at similar OA loadings to constrain the condensation sink in the calculation. Figure S11 shows a typical application for our OFR conditions during the ambient measurements. The dominant fate of LVOCs is to condense onto aerosols, which explains over $95 \%$ of the fate for the studied photochemical ages. This fraction is much greater than other ambient studies, explained by high OA loadings in the reactor in our case. $^{11-13}$

The differences of RH in the ambient air and in the OFR were observed (Figure S7), which was probably driven by the sensor difference in precision and response time with additional contribution of lamp heating and consumption of water vapor in the OFR (i.e., $185 \mathrm{~nm}$ lights photolyze water vapor and $\mathrm{O}\left({ }^{1} \mathrm{D}\right)$ reacts with water vapor). The $\mathrm{RH} / \mathrm{T}$ sensor was located between the center line and the lamps in the OFR. Strong temperature gradients in the OFR are not expected because the flow in OFR is not ideal laminar flow and the residence time of OFR is relatively short. ${ }^{14}$ The consumption of water vapor perhaps has minor impacts on the $\mathrm{RH}$ based on the PAM-Chem calculation. The sensor difference is important. We used Rotronic 
HC2-S3 for ambient and Sensirion SHT21 for OFR RH/T measurements. As shown in Figure S17, we tested the sensors in the lab and the two sensors may be different by $2-10 \% \mathrm{RH}$ depending on the response curve. Nevertheless, less than $10 \%$ of the difference in RH would not affect much the SOA yields of anthropogenic VOCs.

\section{S2.4 Other Instruments}

Other instruments included gas analyzers, a weather station, a global positioning system (GPS) and 4 video cameras. Gas analyzers were used to measure $\mathrm{CO}_{2}, \mathrm{NO}_{2}, \mathrm{NO}, \mathrm{SO}_{2}, \mathrm{O}_{3}$, and, $\mathrm{CO}$ with detection ranges (precision) of 0-1000 ppm (1\%), 0-500 ppb (0.5\%), 0-500 ppb (1\%), 0-500 ppb (0.5\%), 0-20 ppm (0.5\%), and 0-10 ppm (1\%), respectively. The Licor Li-7500 $\mathrm{CO}_{2}$ analyzer, an absolute, non-dispersive, open-path infrared analyzer, was put on top of the mobile laboratory near the sampling inlet port. The Teledyne T500U $\mathrm{NO}_{2}$ analyzer is based on a Cavity Attenuated Phase Shift (CAPS) spectroscopy technique. The Ecotech 9841A $\mathrm{NO}_{x}$ analyzer using a chemiluminescent technique to provide $\mathrm{NO}$ concentrations. The Ecotech $9850 \mathrm{~A} \mathrm{SO}_{2}$ analyzer is based on a fluorescence technique. The Ecotech $9810 \mathrm{~A} \mathrm{O}_{3}$ analyzer is a nondispersive ultraviolet (UV) photometer. The four gas analyzers above measured the gases downstream the OFR via a glass manifold. The Ecotech 9830A CO analyzer, based on CO absorption of non-dispersive infrared radiation (NDIR) at a wavelength of 4.6 microns, measured ambient $\mathrm{CO}$ concentrations directly through a 3-m $1 / 4$ inch (O.D.) Teflon tube. The weather station contains a sensor, which can measure temperature from -40 to $60{ }^{\circ} \mathrm{C}$ and relative humidity from 0 to $100 \%$. All the measurement data were recorded with an industrial personal computer (IPC). A GPS (Goome, GM02F) provided precise latitude and longitude data for spatial analysis as well as calculation of moving speed. Four video cameras installed 
at the four side of the mobile laboratory provided continuous views of on-road conditions all around to identify potential emission sources.

\section{Section 3. Mobile Laboratory Set-up}

An isokinetic sampling system was designed to minimize aerosol aerodynamic losses due to high moving speed of the mobile laboratory. The typical speed was $60 \pm 5 \mathrm{~km} \mathrm{~h}^{-1}(\sim 16.67$ $\mathrm{m} \mathrm{s}^{-1}$ ), airflows containing particles were forced horizontally into the cone-shaped stainless steel tube with the inlet of $4.5 \mathrm{~mm} \mathrm{OD}$, and the body of 3/4-inch OD. A bypass flow was to made up flow rate to be about 15.9 SLPM at the inlet so that the linear velocity was same as the speed of the mobile lab. The sample flow was decelerated to $1.2 \pm 0.2 \mathrm{~m} \mathrm{~s}^{-1}$ at laminar flow (Flow Reynolds number $\mathrm{Re}<2000$ ). The exhaust flow was discarded backwards. To maintain a constant sampling flow rate, the mobile laboratory was kept at a constant speed of $60 \pm 5 \mathrm{~km}$ $\mathrm{h}^{-1}$ during on-road measurements when the road conditions permitted. The glass manifold is described in detail by Wang et al. ${ }^{15}$ Briefly, it is composed of two glass tubes. Air flow came through the inside tube and then into the outer tube to exclude coarse particles by gravity and prevent condensation when the temperature difference between inside and outside the mobile lab was large. These gases were then diverted to each of the gas analyzers through Teflon tubes by their inner pumps. $\mathrm{CO}$ analyzer always sampled ambient air during this campaign through a 1/4-inch Teflon tube.

We performed tests to investigate self-contamination at the midnight of clean days, when the concentrations of pollutants were pretty low and the wind was mild. Very high concentrations of $\mathrm{NO}_{x}$ and $\mathrm{CO}_{2}$ (main vehicle emissions) were observed during the cold start. When driving at $30 \mathrm{~km} \mathrm{~h}^{-1}$, the level of pollutants was the same as the background, implying 
little self-contamination for target pollutants when driving over $30 \mathrm{~km} \mathrm{~h}^{-1}$ without wind effect (Figure S3).

\section{Section 4. Determination of $\Delta \mathrm{OA}_{\mathrm{AE}} / \Delta \mathrm{CO}$}

The SOA potential is certain under the certain oxidative aging for one emission source (i.e. fleet vehicle emissions in this study). The SOA potential of fleet vehicle emissions can be expressed as the following equations:

$$
\begin{gathered}
\mathrm{OA}_{\mathrm{OFR}}=\mathrm{OA}_{\text {background }}+\mathrm{OA}_{\text {emissions }}+\mathrm{SOA}=\mathrm{OA}_{\text {bypass }}+\mathrm{SOA} \\
\mathrm{CO}_{\text {measured }}=\mathrm{CO}_{\text {background }}+\mathrm{CO}_{\text {emissions }} \\
\mathrm{SOAP}=\mathrm{SOA} / \mathrm{CO}_{\text {emissions }}=\left(\mathrm{OA}_{\mathrm{OFR}}-\mathrm{OA}_{\text {bypass }}\right) /\left(\mathrm{CO}_{\text {measured }}-\mathrm{CO}_{\text {background }}\right)=\mathrm{OA}_{\mathrm{AE}} / \\
\left(\mathrm{CO}_{\text {measured }}-\mathrm{CO}_{\text {background }}\right) \\
\mathrm{OA}_{\mathrm{AE}}=\mathrm{SOAP} \times \mathrm{CO}_{\text {measured }}-\mathrm{SOAP} \times \mathrm{CO}_{\text {background }}
\end{gathered}
$$

The background concentration of $\mathrm{CO}$ is unknown and has the large propagated error if determined by a chosen fixed background site, especially for mobile sampling with spatial variations. Assuming that $\mathrm{CO}$ background is relatively similar within a several-hour sampling period, the intercept is relatively certain under the certain oxidative aging.

Determinations of $\mathrm{OH}$ exposure based on the decay of the tracer species are most accurate in the range of $10 \%-90 \%$ of the decay proportion. ${ }^{6}$ According to kinetic properties $\left(k_{\mathrm{OH}}\right)$ of benzene and toluene (Section S2), we extract the data with the equivalent photochemical age between 0.5-4.5 days and categorize them every 0.5 days as an interval. We performed the Reduced Major Axis Regression, implemented in the Lmodel2 in R studio software package. The slopes of $\mathrm{OA}_{\mathrm{AE}}$ and $\mathrm{CO}$ in the panels of Figure $\mathrm{S} 10$ are 39, 44, 35, 33, 26, 24, 19, and 22, respectively, which represent statistically-meaningful SOA potential in the unit of $\mu \mathrm{g} \mathrm{OA} \mathrm{m}{ }^{-3}$ 
ppmv $^{-1} \mathrm{CO}$ in the equivalent photochemical ages of $0.8,1.3,1.8,2.2,2.7,3.3,3.7$, and 4.1 days. Extrapolations of the regression lines (i.e. the intercepts of the $\mathrm{x}$-axis) are meaningless because the method is efficient in pollution-dominated air masses. The light grey points are outliers, extracted by Bonferroni Outlier Test, which might be partly due to the insufficient representative of average fleet and/or the different $\mathrm{CO}$ background. Although the temporal variations of $\mathrm{CO}$ background values have been eliminated due to the similarity of the sampling time of the points in each panel, the spatial variations still exist resulting in the scatter of the points. The grey lines show the 95\% confidence intervals of the regressions.

\section{Section 5. Predicted SOA formation}

SOA formation were predicted on the basis of the following criteria:

1). We assumed that the species whose concentrations decreased after oxidation in the OFR can potentially be SOA precursors. $\mathrm{C}_{2}-\mathrm{C}_{4}$ carbonyls can be SOA precursors, but they were also easy to be largely produced during oxidation in the OFR, so we ignored them when predicting SOA formation. Contributions of fragments for targeted ions in PTR-QiTOF were ignored.

2). For the species in Table S3, SOA formation was calculated using the method of SOA yield parameterization:

$$
\mathrm{SOA}_{i}=\Delta \mathrm{VOC}_{i} \times \mathrm{Y}_{i}(T)
$$

where, $\Delta \mathrm{VOC}_{i}$ is the difference of the concentrations for species $i$ between the ambient and the downstream of the OFR; $\mathrm{Y}_{i}(T)$ is the SOA yield for species $i$, determined according to massdependent SOA yield curves based on gas/particle absorptive partitioning theory through smog chamber experiments. ${ }^{16-18}$ Four-product and two-product models of SOA yield parameterization were used as follow: 


$$
\begin{gathered}
\mathrm{Y}_{i}(T)=\Sigma\left[\alpha_{i}\left(1+\frac{C_{i}^{*}(T)}{\mathrm{M}_{0}}\right)^{-1}\right] \\
\mathrm{Y}_{i}(T)=\mathrm{M}_{0}\left[\frac{\alpha_{1} K_{\mathrm{om}, 1}(T)}{1+K_{\mathrm{om}, 1}(T) \mathrm{M}_{0}}+\frac{\alpha_{2} K_{\mathrm{om}, 2}(T)}{1+K_{\mathrm{om}, 2}(T) \mathrm{M}_{0}}\right]
\end{gathered}
$$

where, $\mathrm{M}_{0}$ is OA concentrations measured downstream of the OFR. SOA yields herein were adjusted to the reference temperature via the Clausius-Clapeyron equation:

$$
\begin{gathered}
C_{i}^{*}(T)=C_{i}^{*}\left(T_{0}\right) \frac{T_{0}}{T} \exp \left[\frac{\Delta H_{\text {vap }}}{\mathrm{R}}\left(\frac{1}{T_{0}}-\frac{1}{T}\right)\right] \\
K_{\text {om }, i}(T)=\frac{1}{C_{i}^{*}(T)}
\end{gathered}
$$

where, $T_{0}$ is the mean temperature in the smog chamber studies (i.e. $298 \mathrm{~K}$ ); $T$ is the reference temperature, which represents the mean value of ambient temperature during the measurement periods (i.e. $281 \mathrm{~K})$; the reference effective enthalpy of vaporization used herein $\left(\Delta H_{\text {vap }}\right)$ was $42 \mathrm{~kJ} \mathrm{~mol}^{-1}$ given the literature range of $11-44 .{ }^{21} \mathrm{We}$ refitted the yield curves from the recent smog chamber studies especially under high- $\mathrm{NO}_{x}$ condition as listed in Table S3.

3). For the species that lack any yield curves in Table S4a, Secondary Organic Aerosol Potential (SOAP) ${ }^{19}$ method was employed to calculate predicted SOA formation:

$$
\mathrm{SOA}_{i}=\frac{\mathrm{SOAP}_{i} \times \Delta \mathrm{VOC}_{i} \times \mathrm{SOA}_{\text {toluene }}}{\Delta \mathrm{VOC}_{\text {toluene }}} \div 100
$$

where, $\mathrm{SOAP}_{i}$ reflects the propensity of species $i$ to form SOA on an equal mass emitted basis relative to toluene, which is calculated based on Master Chemical Mechanism under highly idealized conditions.

$$
\mathrm{SOAP}_{i}=\frac{\text { Increment in SOA mass concentration with species, } i}{\text { Increment in SOA with toluene }} \times 100
$$

4). For the species that lack any yield curves in Table S4b, Fractional Aerosol Coefficient $(\mathrm{FAC})^{20}$ method was employed to calculate predicted SOA formation:

$$
\mathrm{SOA}_{i}=\mathrm{FAC}_{i} \times \mathrm{VOC}_{i, \text { ambient }}
$$


where, $\mathrm{FAC}_{i}$ describes the fraction of species $i$ converted to be OA, which is the results of smog chamber experiments.

5). Priority was given to the highest SOA yield among isomers. 


\section{Reference}

(1) Tkacik, D. S.; Lambe, A. T.; Jathar, S.; Li, X.; Presto, A. A.; Zhao, Y. L.; Blake, D.; Meinardi, S.; Jayne, J. T.; Croteau, P. L.; Robinson, A. L. Secondary organic aerosol formation from in-use motor vehicle emissions using a potential aerosol mass reactor. Environ. Sci. Technol. 2014, 48 (19), 11235-11242.

(2) Huang, G. C.; Liu, Y.; Shao, M.; Li, Y.; Chen, Q.; Zheng, Y.; Wu, Z. J.; Liu, Y. C.; Wu, Y. S.; Hu, M.; Li, X.; Lu, S. H.; Wang, C. J.; Liu, J. Y.; Zheng, M.; Zhu, T. Potentially important contribution of gas-phase oxidation of naphthalene and methylnaphthalene to secondary organic aerosol during haze events in Beijing. Environ. Sci. Technol. 2019, 53 (3), 1235-1244.

(3) Cappellin, L.; Karl, T.; Probst, M.; Ismailova, O.; Winkler, P. M.; Soukoulis, C.; Aprea, E.; Mark, T. D.; Gasperi, F.; Biasioli, F. On Quantitative Determination of Volatile Organic Compound Concentrations Using Proton Transfer Reaction Time-of-Flight Mass Spectrometry. Environ. Sci. Technol. 2012, 46 (4), 2283-2290. (4) Zheng, Y.; Cheng, X.; Liao, K. R.; Li, Y. W.; Li, Y. J.; Hu, W. W.; Liu, Y.; Zhu, T.; Chen, S. Y.; Zeng, L. M.; Worsnop, D.; Chen, Q.; Huang, R. J. Characterization of anthropogenic organic aerosols by TOF-ACSM with the new capture vaporizer. Atmos. Meas. Tech. 2020, 13 (5), 2457-2472.

(5) Ortega, A. M.; Day, D. A.; Cubison, M. J.; Brune, W. H.; Bon, D.; de Gouw, J. A.; Jimenez, J. L. Secondary organic aerosol formation and primary organic aerosol oxidation from biomass-burning smoke in a flow reactor during FLAME-3. Atmos. Chem. Phys. 2013, 13 (22), 11551-11571.

(6) Li, R.; Palm, B. B.; Ortega, A. M.; Hlywiak, J.; Hu, W. W.; Peng, Z.; Day, D. A.; Knote, C.; Brune, W. H.; de Gouw, J. A.; Jimenez, J. L. Modeling the radical chemistry in an oxidation flow reactor: radical formation and recycling, sensitivities, and the $\mathrm{OH}$ exposure estimation equation. J. Phys. Chem. A 2015, 119 (19), 4418-4432.

(7) Peng, Z.; Jimenez, J. L. Radical chemistry in oxidation flow reactors for atmospheric chemistry research. Chem. Soc. Rev. 2020, 49 (9), 2570-2616.

(8) Mao, J.; Ren, X.; Brune, W. H.; Olson, J. R.; Crawford, J. H.; Fried, A.; Huey, L. G.; Cohen, R. C.; Heikes, 
B.; Singh, H. B.; Blake, D. R.; Sachse, G. W.; Diskin, G. S.; Hall, S. R.; Shetter, R. E. Airborne measurement of OH reactivity during INTEX-B. Atmos. Chem. Phys. 2009, 9 (1), 163-173.

(9) Atkinson, R.; Arey, J. Atmospheric degradation of volatile organic compounds. Chem. Rev. 2003, 103 (12), 4605-4638.

(10) Palm, B. B.; Campuzano-Jost, P.; Ortega, A. M.; Day, D. A.; Kaser, L.; Jud, W.; Karl, T.; Hansel, A.; Hunter, J. F.; Cross, E. S.; Kroll, J. H.; Peng, Z.; Brune, W. H.; Jimenez, J. L. In situ secondary organic aerosol formation from ambient pine forest air using an oxidation flow reactor. Atmos. Chem. Phys. 2016, 16 (5), 2943-2970.

(11) Saha, P. K.; Reece, S. M.; Grieshop, A. P. Seasonally varying secondary organic aerosol formation from insitu oxidation of near-highway air. Environ. Sci. Technol. 2018, 52 (13), 7192-7202.

(12) Liu, T. Y.; Zhou, L. Y.; Liu, Q. Y.; Lee, B. P.; Yao, D. W.; Lu, H. X.; Lyu, X. P.; Guo, H.; Chan, C. K. Secondary organic aerosol formation from urban roadside air in Hong Kong. Environ. Sci. Technol. 2019, 53 (6), 3001-3009.

(13) Shah, R. U.; Coggon, M. M.; Gkatzelis, G. I.; McDonald, B. C.; Tasoglou, A.; Huber, H.; Gilman, J.; Warneke, C.; Robinson, A. L.; Presto, A. A. Urban oxidation flow reactor measurements reveal significant secondary organic aerosol contributions from volatile emissions of emerging importance. Environ. Sci. Technol. 2020, 54 (2), 714-725.

(14) Lambe, A. T.; Ahern, A. T.; Williams, L. R.; Slowik, J. G.; Wong, J. P. S.; Abbatt, J. P. D.; Brune, W. H.; Ng, N. L.; Wright, J. P.; Croasdale, D. R.; Worsnop, D. R.; Davidovits, P.; Onasch, T. B. Characterization of aerosol photooxidation flow reactors: heterogeneous oxidation, secondary organic aerosol formation and cloud condensation nuclei activity measurements. Atmos. Meas. Tech. 2011, 4 (3), 445-461.

(15) Wang, M.; Zhu, T.; Zheng, J.; Zhang, R. Y.; Zhang, S. Q.; Xie, X. X.; Han, Y. Q.; Li, Y. Use of a mobile laboratory to evaluate changes in on-road air pollutants during the Beijing 2008 Summer Olympics. Atmos. Chem. 
Phys. 2009, 9 (21), 8247-8263.

(16) Odum, J. R.; Hoffmann, T.; Bowman, F.; Collins, D.; Flagan, R. C.; Seinfeld, J. H. Gas/particle partitioning and secondary organic aerosol yields. Environ. Sci. Technol. 1996, 30 (8), 2580-2585.

(17) Odum, J. R.; Jungkamp, T. P. W.; Griffin, R. J.; Flagan, R. C.; Seinfeld, J. H. The atmospheric aerosolforming potential of whole gasoline vapor. Science 1997, 276 (5309), 96-99.

(18) Donahue, N. M.; Robinson, A. L.; Stanier, C. O.; Pandis, S. N. Coupled partitioning, dilution, and chemical aging of semivolatile organics. Environ. Sci. Technol. 2006, 40 (8), 2635-2643.

(19) Derwent, R. G.; Jenkin, M. E.; Utembe, S. R.; Shallcross, D. E.; Murrells, T. P.; Passant, N. R. Secondary organic aerosol formation from a large number of reactive man-made organic compounds. Sci. Total Environ. 2010, 408 (16), 3374-3381.

(20) Grosjean, D.; Seinfeld, J. H. Parameterization of the formation potential of secondary organic aerosols. Atmos. Environ. 1989, 23 (8), 1733-1747.

(21) Offenberg, J. H.; Kleindienst, T. E.; Jaoui, M.; Lewandowski, M.; Edney, E. O. Thermal properties of secondary organic aerosols. Geophys. Res. Lett. 2006, 33 (3), 4.

(22) Ng, N. L.; Kroll, J. H.; Chan, A. W. H.; Chhabra, P. S.; Flagan, R. C.; Seinfeld, J. H. Secondary organic aerosol formation from m-xylene, toluene, and benzene. Atmos. Chem. Phys. 2007, 7 (14), 3909-3922.

(23) Xu, J. L.; Griffin, R. J.; Liu, Y.; Nakao, S.; Cocker, D. R. Simulated impact of NOx on SOA formation from oxidation of toluene and m-xylene. Atmos. Environ. 2015, 101, 217-225.

(24) Song, C.; Na, K.; Warren, B.; Malloy, Q.; Cocker, D. R. Secondary organic aerosol formation from the photooxidation of p- and o-xylene. Environ. Sci. Technol. 2007, 41 (21), 7403-7408.

(25) Wyche, K. P.; Monks, P. S.; Ellis, A. M.; Cordell, R. L.; Parker, A. E.; Whyte, C.; Metzger, A.; Dommen, J.; Duplissy, J.; Prevot, A. S. H.; Baltensperger, U.; Rickard, A. R.; Wulfert, F. Gas phase precursors to 
anthropogenic secondary organic aerosol: detailed observations of 1,3,5-trimethylbenzene photooxidation. Atmos. Chem. Phys. 2009, 9 (2), 635-665.

(26) Ng, N. L.; Chhabra, P. S.; Chan, A. W. H.; Surratt, J. D.; Kroll, J. H.; Kwan, A. J.; McCabe, D. C.; Wennberg, P. O.; Sorooshian, A.; Murphy, S. M.; Dalleska, N. F.; Flagan, R. C.; Seinfeld, J. H. Effect of NOx level on secondary organic aerosol (SOA) formation from the photooxidation of terpenes. Atmos. Chem. Phys. 2007, 7 (19), 5159-5174.

(27) Eddingsaas, N. C.; Loza, C. L.; Yee, L. D.; Chan, M.; Schilling, K. A.; Chhabra, P. S.; Seinfeld, J. H.; Wennberg, P. O. alpha-pinene photooxidation under controlled chemical conditions - Part 2: SOA yield and composition in low- and high-NOx environments. Atmos. Chem. Phys. 2012, 12 (16), 7413-7427.

(28) Han, Y. M.; Stroud, C. A.; Liggio, J.; Li, S. M. The effect of particle acidity on secondary organic aerosol formation from alpha-pinene photooxidation under atmospherically relevant conditions. Atmos. Chem. Phys. 2016, $16(21), 13929-13944$.

(29) Sarrafzadeh, M.; Wildt, J.; Pullinen, I.; Springer, M.; Kleist, E.; Tillmann, R.; Schmitt, S. H.; Wu, C.; Mentel, T. F.; Zhao, D. F.; Hastie, D. R.; Kiendler-Scharr, A. Impact of NOx and $\mathrm{OH}$ on secondary organic aerosol formation from beta-pinene photooxidation. Atmos. Chem. Phys. 2016, 16 (17), 11237-11248.

(30) Chan, A. W. H.; Kautzman, K. E.; Chhabra, P. S.; Surratt, J. D.; Chan, M. N.; Crounse, J. D.; Kurten, A.; Wennberg, P. O.; Flagan, R. C.; Seinfeld, J. H. Secondary organic aerosol formation from photooxidation of naphthalene and alkylnaphthalenes: Implications for oxidation of intermediate volatility organic compounds (IVOCs). Atmos. Chem. Phys. 2009, 9 (9), 3049-3060.

(31) Gomez Alvarez, E.; Borras, E.; Viidanoja, J.; Hjorth, J. Unsaturated dicarbonyl products from the OHinitiated photo-oxidation of furan, 2-methylfuran and 3-methylfuran. Atmos. Environ. 2009, 43 (9), 1603-1612.

(32) Yee, L. D.; Kautzman, K. E.; Loza, C. L.; Schilling, K. A.; Coggon, M. M.; Chhabra, P. S.; Chan, M. N.; 
Chan, A. W. H.; Hersey, S. P.; Crounse, J. D.; Wennberg, P. O.; Flagan, R. C.; Seinfeld, J. H. Secondary organic aerosol formation from biomass burning intermediates: phenol and methoxyphenols. Atmos. Chem. Phys. 2013, $13(16), 8019-8043$.

(33) Hu, W. W.; Campuzano-Jost, P.; Day, D. A.; Croteau, P.; Canagaratna, M. R.; Jayne, J. T.; Worsnop, D. R.; Jimenez, J. L. Evaluation of the new capture vapourizer for aerosol mass spectrometers (AMS) through laboratory studies of inorganic species. Atmos. Meas. Tech. 2017, 10 (8), 2897-2921. 
Table S1. Instrumentations deployed in the PKU Mobile Laboratory. All instruments were calibrated before, in the middle and end of the campaign.

\begin{tabular}{ccc}
\hline Instrumentation, Manufacture and Model & Measures & Sampling frequency \\
\hline TOF-ACSM, Aerodyne & Organics, Nitrate, Sulfate, & $40 \mathrm{~s}$ \\
Ammonium, Chloride in $\mathrm{PM}_{2.5}$ & \\
PTR-QiTOF, Ionicon & VOCs (Table S2) & $2 \mathrm{~s}$ \\
LICOR, Li-Cor LI7500 & $\mathrm{CO}_{2}$ & $2 \mathrm{~s}$ \\
$\mathrm{NO}_{2}$ monitor, Teledyne T500U & $\mathrm{NO}_{2}$ & $2 \mathrm{~s}$ \\
$\mathrm{NO}_{x}$ analyzer, Ecotech EC9841A & $\mathrm{NO}$ & $2 \mathrm{~s}$ \\
$\mathrm{CO}_{\text {analyzer, Ecotech EC9830A }}$ & $\mathrm{CO}$ & $2 \mathrm{~s}$ \\
$\mathrm{O}_{3}$ analyzer, Ecotech EC9810A & $\mathrm{O}_{3}$ & $2 \mathrm{~s}$ \\
$\mathrm{SO}_{2}$ analyzer, Ecotech EC9850A & $\mathrm{SO}_{2}$ & $2 \mathrm{~s}$ \\
OFR, Aerodyne & - & - \\
\hline
\end{tabular}


Table S2. List of species measured by PTR-QiTOF.

\begin{tabular}{|c|c|c|c|c|c|c|c|}
\hline $\begin{array}{l}\text { Nominal } \\
\text { mass }\end{array}$ & Protonated ion & $m / z$ & $\begin{array}{l}k\left(10^{-9}\right. \\
\left.\mathrm{cm}^{3} \mathrm{~s}^{-1}\right)\end{array}$ & $\begin{array}{l}\text { Nominal } \\
\text { mass }\end{array}$ & Protonated ion & $m / z$ & $\begin{array}{l}k\left(10^{-9}\right. \\
\left.\mathrm{cm}^{3} \mathrm{~s}^{-1}\right)\end{array}$ \\
\hline 42 & $\left(\mathrm{CH}_{3} \mathrm{CN}\right) \mathrm{H}^{+}$ & 42.034 & 2 & 107 & $\left(\mathrm{C}_{7} \mathrm{H}_{6} \mathrm{O}\right) \mathrm{H}^{+}$ & 107.049 & 4.12 \\
\hline 43 & $\left(\mathrm{C}_{2} \mathrm{H}_{2} \mathrm{O}\right) \mathrm{H}^{+}$ & 43.018 & 2.21 & 107 & $\left(\mathrm{C}_{8} \mathrm{H}_{10}\right) \mathrm{H}^{+}$ & 107.086 & 2.29 \\
\hline 43 & $\left(\mathrm{C}_{3} \mathrm{H}_{6}\right) \mathrm{H}^{+}$ & 43.054 & 1.58 & 113 & $\left(\mathrm{C}_{5} \mathrm{H}_{4} \mathrm{O}_{3}\right) \mathrm{H}^{+}$ & 113.023 & 2 \\
\hline 45 & $\left(\mathrm{CH}_{3} \mathrm{CHO}\right) \mathrm{H}^{+}$ & 45.033 & 3.36 & 113 & $\left(\mathrm{C}_{6} \mathrm{H}_{8} \mathrm{O}_{2}\right) \mathrm{H}^{+}$ & 113.060 & 2 \\
\hline 47 & $(\mathrm{HCOOH}) \mathrm{H}^{+}$ & 47.013 & 2.02 & 113 & $\left(\mathrm{C}_{7} \mathrm{H}_{12} \mathrm{O}\right) \mathrm{H}^{+}$ & 113.096 & 2 \\
\hline 57 & $\left(\mathrm{C}_{3} \mathrm{H}_{4} \mathrm{O}\right) \mathrm{H}^{+}$ & 57.033 & 3.35 & 115 & $\left(\mathrm{C}_{5} \mathrm{H}_{6} \mathrm{O}_{3}\right) \mathrm{H}^{+}$ & 115.039 & 2 \\
\hline 57 & $\left(\mathrm{C}_{4} \mathrm{H}_{8}\right) \mathrm{H}^{+}$ & 57.070 & 1.76 & 115 & $\left(\mathrm{C}_{6} \mathrm{H}_{10} \mathrm{O}_{2}\right) \mathrm{H}^{+}$ & 115.075 & 2 \\
\hline 59 & $\left(\mathrm{C}_{3} \mathrm{H}_{6} \mathrm{O}\right) \mathrm{H}^{+}$ & 59.049 & 3 & 115 & $\left(\mathrm{C}_{7} \mathrm{H}_{14} \mathrm{O}\right) \mathrm{H}^{+}$ & 115.112 & 3.14 \\
\hline 61 & $\left(\mathrm{C}_{2} \mathrm{H}_{4} \mathrm{O}_{2}\right) \mathrm{H}^{+}$ & 61.028 & 2.27 & 117 & $\left(\mathrm{C}_{4} \mathrm{H}_{4} \mathrm{O}_{4}\right) \mathrm{H}^{+}$ & 117.018 & 2 \\
\hline 63 & $\left(\mathrm{C}_{2} \mathrm{H}_{6} \mathrm{~S}\right) \mathrm{H}^{+}$ & 63.026 & 2 & 117 & $\left(\mathrm{C}_{5} \mathrm{H}_{8} \mathrm{O}_{3}\right) \mathrm{H}^{+}$ & 117.055 & 2 \\
\hline 69 & $\left(\mathrm{C}_{4} \mathrm{H}_{4} \mathrm{O}\right) \mathrm{H}^{+}$ & 69.033 & 1.78 & 117 & $\left(\mathrm{C}_{6} \mathrm{H}_{12} \mathrm{O}_{2}\right) \mathrm{H}^{+}$ & 117.091 & 2 \\
\hline 69 & $\left(\mathrm{C}_{5} \mathrm{H}_{8}\right) \mathrm{H}^{+}$ & 69.070 & 1.94 & 121 & $\left(\mathrm{C}_{8} \mathrm{H}_{8} \mathrm{O}\right) \mathrm{H}^{+}$ & 121.065 & 3.84 \\
\hline 71 & $\left(\mathrm{C}_{4} \mathrm{H}_{6} \mathrm{O}\right) \mathrm{H}^{+}$ & 71.049 & 3.83 & 121 & $\left(\mathrm{C}_{9} \mathrm{H}_{12}\right) \mathrm{H}^{+}$ & 121.101 & 2.47 \\
\hline 73 & $\left(\mathrm{C}_{3} \mathrm{H}_{4} \mathrm{O}_{2}\right) \mathrm{H}^{+}$ & 73.028 & 2.67 & 123 & $\left(\mathrm{C}_{7} \mathrm{H}_{6} \mathrm{O}_{2}\right) \mathrm{H}^{+}$ & 123.044 & 3.02 \\
\hline 73 & $\left(\mathrm{C}_{4} \mathrm{H}_{8} \mathrm{O}\right) \mathrm{H}^{+}$ & 73.065 & 3.48 & 123 & $\left(\mathrm{C}_{8} \mathrm{H}_{10} \mathrm{O}\right) \mathrm{H}^{+}$ & 123.080 & 2 \\
\hline 75 & $\left(\mathrm{C}_{3} \mathrm{H}_{6} \mathrm{O}_{2}\right) \mathrm{H}^{+}$ & 75.044 & 2.41 & 123 & $\left(\mathrm{C}_{9} \mathrm{H}_{14}\right) \mathrm{H}^{+}$ & 123.117 & 2 \\
\hline 77 & $\left(\mathrm{C}_{2} \mathrm{H}_{4} \mathrm{O}_{3}\right) \mathrm{H}^{+}$ & 77.023 & 2 & 129 & $\left(\mathrm{C}_{10} \mathrm{H}_{8}\right) \mathrm{H}^{+}$ & 129.070 & 2.59 \\
\hline 79 & $\left(\mathrm{C}_{6} \mathrm{H}_{6}\right) \mathrm{H}^{+}$ & 79.054 & 1.97 & 137 & $\left(\mathrm{C}_{10} \mathrm{H}_{16}\right) \mathrm{H}^{+}$ & 137.132 & 2.44 \\
\hline 83 & $\left(\mathrm{C}_{5} \mathrm{H}_{6} \mathrm{O}\right) \mathrm{H}^{+}$ & 83.049 & 2 & 143 & $\left(\mathrm{C}_{11} \mathrm{H}_{10}\right) \mathrm{H}^{+}$ & 143.086 & 2 \\
\hline 83 & $\left(\mathrm{C}_{6} \mathrm{H}_{10}\right) \mathrm{H}^{+}$ & 83.086 & 2.16 & 155 & $\left(\mathrm{C}_{12} \mathrm{H}_{10}\right) \mathrm{H}^{+}$ & 155.086 & 2 \\
\hline 87 & $\left(\mathrm{C}_{4} \mathrm{H}_{6} \mathrm{O}_{2}\right) \mathrm{H}^{+}$ & 87.044 & 4.51 & 157 & $\left(\mathrm{C}_{12} \mathrm{H}_{12}\right) \mathrm{H}^{+}$ & 157.101 & 2 \\
\hline 87 & $\left(\mathrm{C}_{5} \mathrm{H}_{10} \mathrm{O}\right) \mathrm{H}^{+}$ & 87.080 & 3.35 & 167 & $\left(\mathrm{C}_{13} \mathrm{H}_{10}\right) \mathrm{H}^{+}$ & 167.086 & 2 \\
\hline 89 & $\left(\mathrm{C}_{3} \mathrm{H}_{4} \mathrm{O}_{3}\right) \mathrm{H}^{+}$ & 89.023 & 2 & 171 & $\left(\mathrm{C}_{13} \mathrm{H}_{14}\right) \mathrm{H}^{+}$ & 171.117 & 2 \\
\hline 89 & $\left(\mathrm{C}_{4} \mathrm{H}_{8} \mathrm{O}_{2}\right) \mathrm{H}^{+}$ & 89.060 & 4.3 & 179 & $\left(\mathrm{C}_{14} \mathrm{H}_{10}\right) \mathrm{H}^{+}$ & 179.086 & 2 \\
\hline 93 & $\left(\mathrm{C}_{7} \mathrm{H}_{8}\right) \mathrm{H}^{+}$ & 93.070 & 2.12 & 181 & $\left(\mathrm{C}_{7} \mathrm{H}_{4} \mathrm{ClF}_{3}\right) \mathrm{H}^{+}$ & 181.003 & 2 \\
\hline 95 & $\left(\mathrm{C}_{6} \mathrm{H}_{6} \mathrm{O}\right) \mathrm{H}^{+}$ & 95.049 & 2.52 & 181 & $\left(\mathrm{C}_{14} \mathrm{H}_{12}\right) \mathrm{H}^{+}$ & 181.101 & 2 \\
\hline 97 & $\left(\mathrm{C}_{5} \mathrm{H}_{4} \mathrm{O}_{2}\right) \mathrm{H}^{+}$ & 97.028 & 4.83 & 185 & $\left(\mathrm{C}_{14} \mathrm{H}_{16}\right) \mathrm{H}^{+}$ & 185.132 & 2 \\
\hline 97 & $\left(\mathrm{C}_{6} \mathrm{H}_{8} \mathrm{O}\right) \mathrm{H}^{+}$ & 97.065 & 2 & 193 & $\left(\mathrm{C}_{15} \mathrm{H}_{12}\right) \mathrm{H}^{+}$ & 193.101 & 2 \\
\hline 97 & $\left(\mathrm{C}_{7} \mathrm{H}_{12}\right) \mathrm{H}^{+}$ & 97.101 & 2.09 & 203 & $\left(\mathrm{C}_{16} \mathrm{H}_{10}\right) \mathrm{H}^{+}$ & 203.086 & 2 \\
\hline 101 & $\left(\mathrm{C}_{4} \mathrm{H}_{4} \mathrm{O}_{3}\right) \mathrm{H}^{+}$ & 101.022 & 2 & 207 & $\left(\mathrm{C}_{16} \mathrm{H}_{14}\right) \mathrm{H}^{+}$ & 207.117 & 2 \\
\hline 101 & $\left(\mathrm{C}_{5} \mathrm{H}_{8} \mathrm{O}_{2}\right) \mathrm{H}^{+}$ & 101.060 & 3.9 & 217 & $\left(\mathrm{C}_{17} \mathrm{H}_{12}\right) \mathrm{H}^{+}$ & 217.101 & 2 \\
\hline 101 & $\left(\mathrm{C}_{6} \mathrm{H}_{12} \mathrm{O}\right) \mathrm{H}^{+}$ & 101.096 & 2.28 & 371 & $\left(\mathrm{C}_{10} \mathrm{H}_{30} \mathrm{O}_{5} \mathrm{Si}_{5}\right) \mathrm{H}^{+}$ & 371.101 & 2 \\
\hline 103 & $\left(\mathrm{C}_{5} \mathrm{H}_{10} \mathrm{O}_{2}\right) \mathrm{H}^{+}$ & 103.075 & 2 & 445 & $\left(\mathrm{C}_{12} \mathrm{H}_{36} \mathrm{O}_{6} \mathrm{Si}_{6}\right) \mathrm{H}^{+}$ & 445.120 & 2 \\
\hline 105 & $\left(\mathrm{C}_{8} \mathrm{H}_{8}\right) \mathrm{H}^{+}$ & 105.070 & 2.33 & & & & \\
\hline
\end{tabular}


Table S3. SOA yields that have been used in this study.

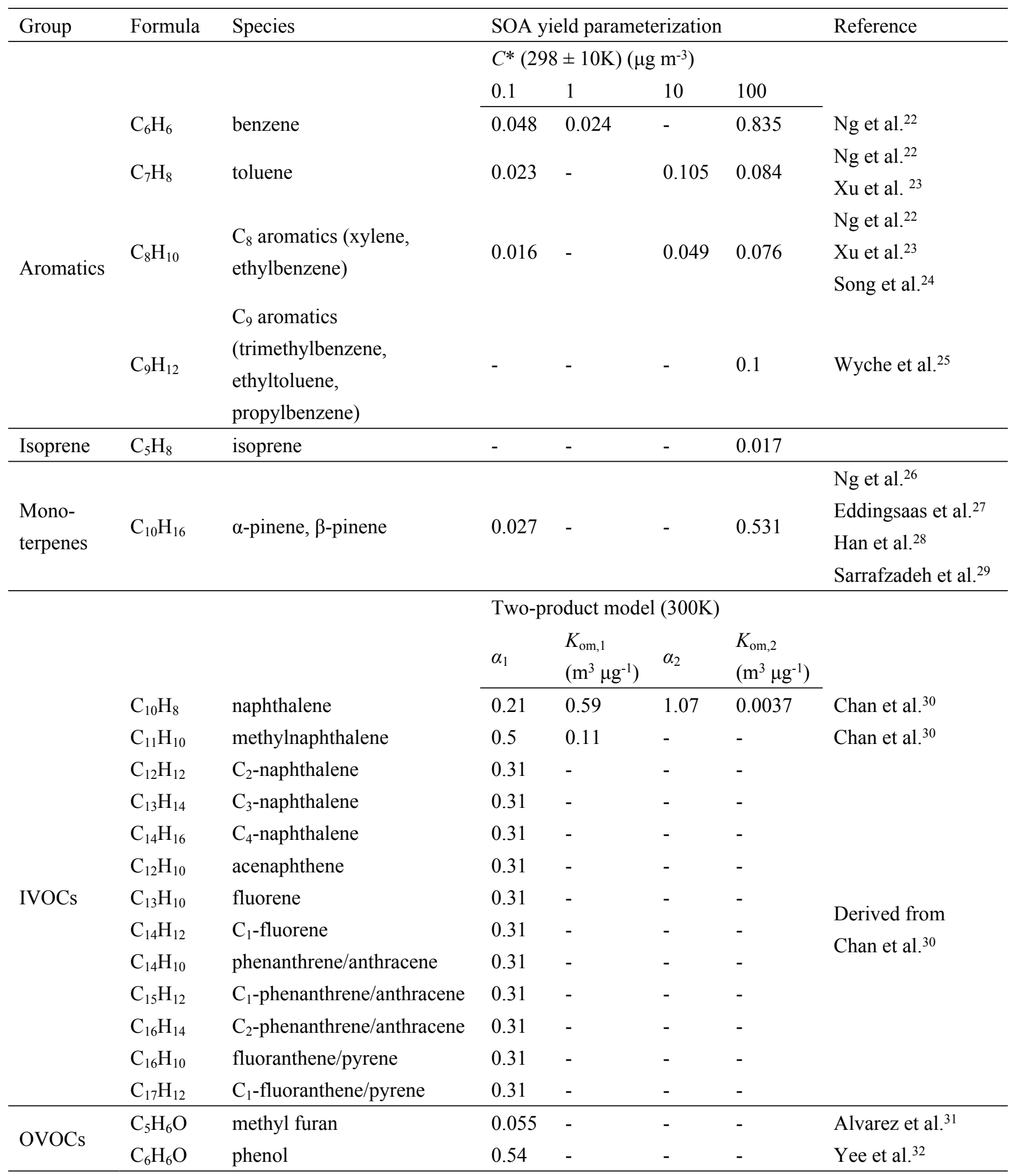


Table S4. SOAP method and FAC method used to predict SOA formation.

\begin{tabular}{|c|c|c|c|c|c|c|}
\hline Part & Method & & Spe & nd parameters & & Reference \\
\hline \multirow{12}{*}{$\mathrm{a}$} & \multirow{12}{*}{$\begin{array}{l}\text { SOAP } \\
\text { method }\end{array}$} & Group & Formula & Species & SOAP & \multirow{12}{*}{$\begin{array}{l}\text { Derwent et } \\
\text { al. }{ }^{19}\end{array}$} \\
\hline & & Aromatics & $\mathrm{C}_{8} \mathrm{H}_{8}$ & styrene & 212.3 & \\
\hline & & \multirow{2}{*}{ Olefins } & $\mathrm{C}_{3} \mathrm{H}_{6}$ & propylene & 1.6 & \\
\hline & & & $\mathrm{C}_{4} \mathrm{H}_{8}$ & butylene & 0.6 & \\
\hline & & \multirow{8}{*}{ OVOCs } & $\mathrm{CH}_{4} \mathrm{O}$ & methanol & 0.3 & \\
\hline & & & $\mathrm{C}_{2} \mathrm{H}_{6} \mathrm{O}$ & ethanol & 0.6 & \\
\hline & & & $\mathrm{C}_{4} \mathrm{H}_{8} \mathrm{O}$ & methyl ethyl ketone & 0.6 & \\
\hline & & & $\mathrm{C}_{4} \mathrm{H}_{8} \mathrm{O}_{2}$ & ethyl acetate & 0.1 & \\
\hline & & & $\mathrm{C}_{5} \mathrm{H}_{10} \mathrm{O}_{2}$ & n-propyl acetate & 0.2 & \\
\hline & & & $\mathrm{C}_{6} \mathrm{H}_{12} \mathrm{O}$ & 3-hexanone & 0.3 & \\
\hline & & & $\mathrm{C}_{6} \mathrm{H}_{12} \mathrm{O}_{2}$ & sec-butyl acetate & 0.3 & \\
\hline & & & $\mathrm{C}_{7} \mathrm{H}_{6} \mathrm{O}$ & benzaldehyde & 216.1 & \\
\hline \multirow{4}{*}{$\mathrm{b}$} & \multirow{4}{*}{$\begin{array}{l}\text { FAC } \\
\text { method }\end{array}$} & Group & Formula & Species & FAC & \\
\hline & & \multirow{3}{*}{ Olefins } & $\mathrm{C}_{6} \mathrm{H}_{10}$ & 1-methylcyclopentene & 0.12 & Grosjean \\
\hline & & & $\mathrm{C}_{7} \mathrm{H}_{12}$ & 1-methylcyclohexene & 0.15 & and \\
\hline & & & $\mathrm{C}_{8} \mathrm{H}_{10} \mathrm{O}$ & $\mathrm{C}_{2}$-substituted phenols & 0.05 & Seinfeld ${ }^{20}$ \\
\hline
\end{tabular}


Table S5. Parameters that have been used in the SOA yield calculation as well as the reference range. For OA concentrations in the OFR and ambient temperature, the $25^{\text {th }}$ and $75^{\text {th }}$ percentiles are listed to correct the literature SOA yields to conditions in the OFR herein.

\begin{tabular}{cccccc}
\hline \multicolumn{1}{c}{ OA } & \multicolumn{2}{c}{ Reference range } & \multicolumn{3}{c}{ Parameters used in yield calculation } \\
$\begin{array}{c}\text { downstream } \\
\text { of the OFR } \\
\left(\mu \mathrm{g} \mathrm{m}^{-3}\right)\end{array}$ & $\begin{array}{c}\text { Ambient } \\
\text { temperature } \\
(\mathrm{K})\end{array}$ & $\begin{array}{c}\text { Literature range of effective } \\
\text { enthalpy of vaporization } \\
\left(\mathrm{kJ} \mathrm{mol}^{-1}\right)^{21}\end{array}$ & $\begin{array}{c}\mathrm{M}_{0} \\
\left(\mu \mathrm{g} \mathrm{m}^{-3}\right)\end{array}$ & $\begin{array}{c}\text { Temperature } \\
(\mathrm{K})\end{array}$ & $\begin{array}{c}\text { Effective } \\
\text { enthalpy of } \\
\text { vaporization }(\mathrm{kJ} \\
\left.\mathrm{mol}^{-1}\right)\end{array}$ \\
\hline $39-70$ & $279-285$ & \multicolumn{5}{c}{$\begin{array}{c}\text { Real-time } \\
\text { OA } \\
\text { downstream } \\
\text { of the OFR }\end{array}$} \\
\hline
\end{tabular}




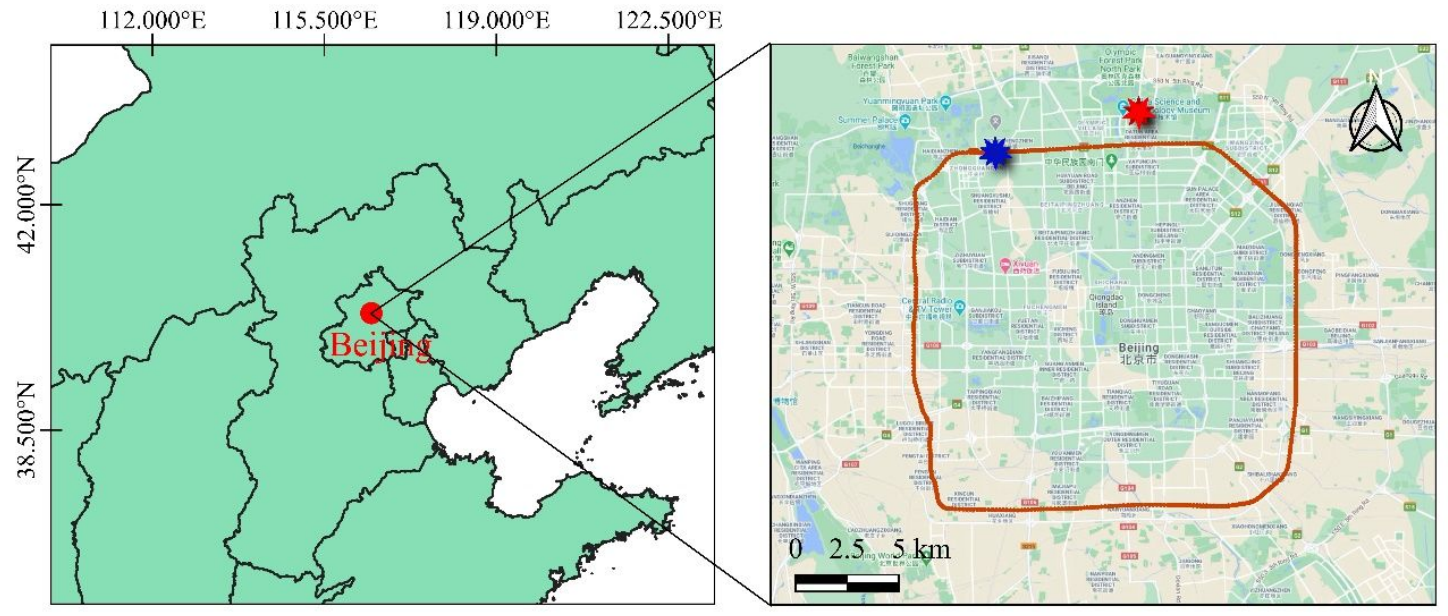

Figure S1. Sampling locations in the $4^{\text {th }}$ Ring Road of Beijing (orange line), Datunlu Tunnel (red star) and the roadside site (blue star). 


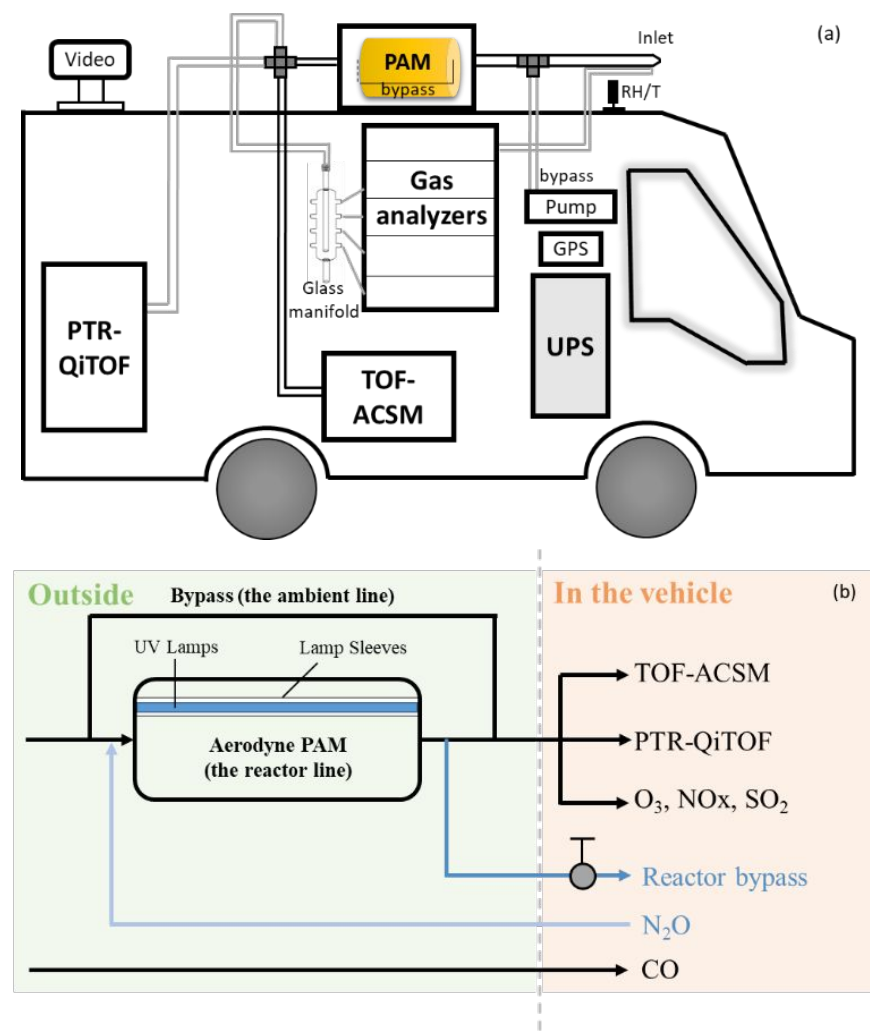

Figure S2. Schematic of the PKU Mobile Laboratory. (a) Sampling setup; (b) Experimental setup in this study. 

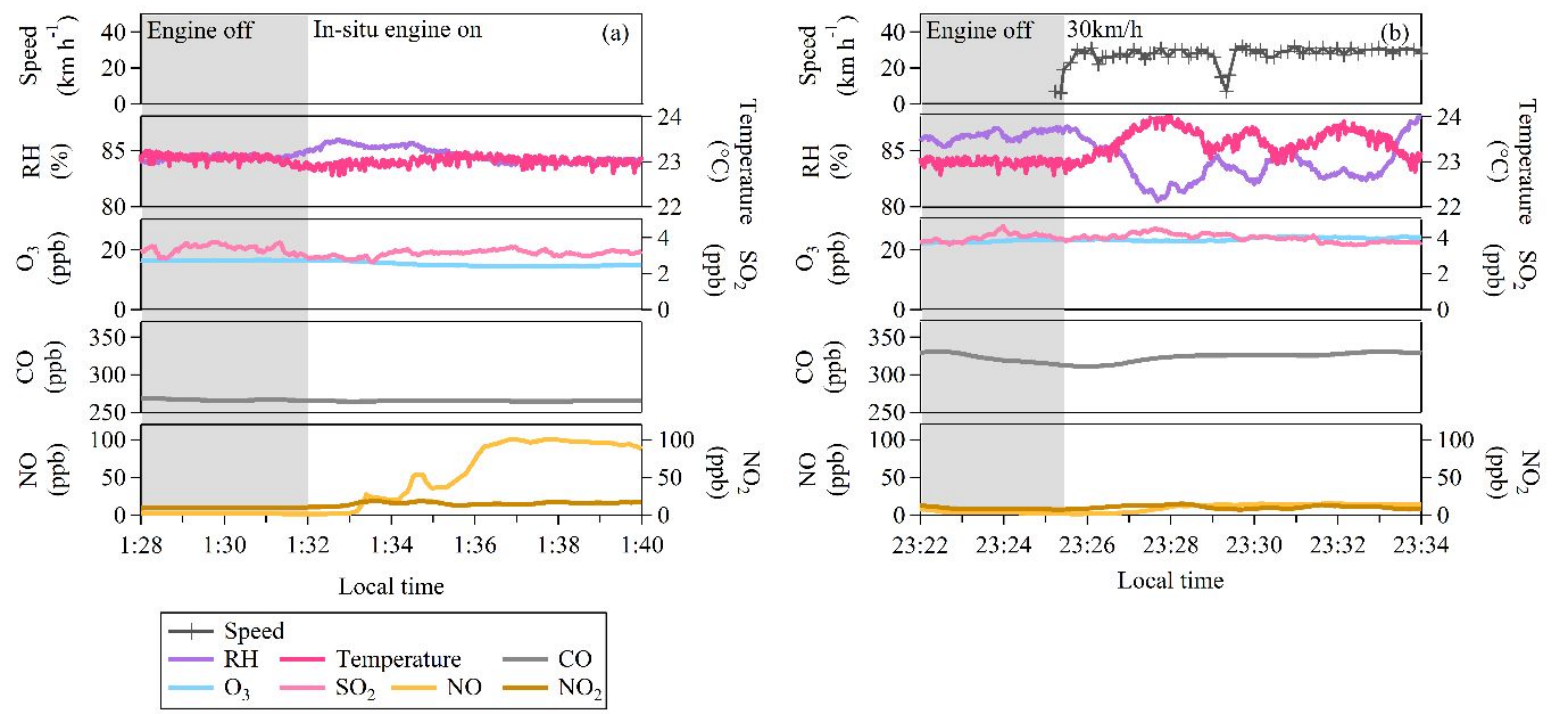

Figure S3. Time series of pollutant concentrations measured during the self-contamination test. 


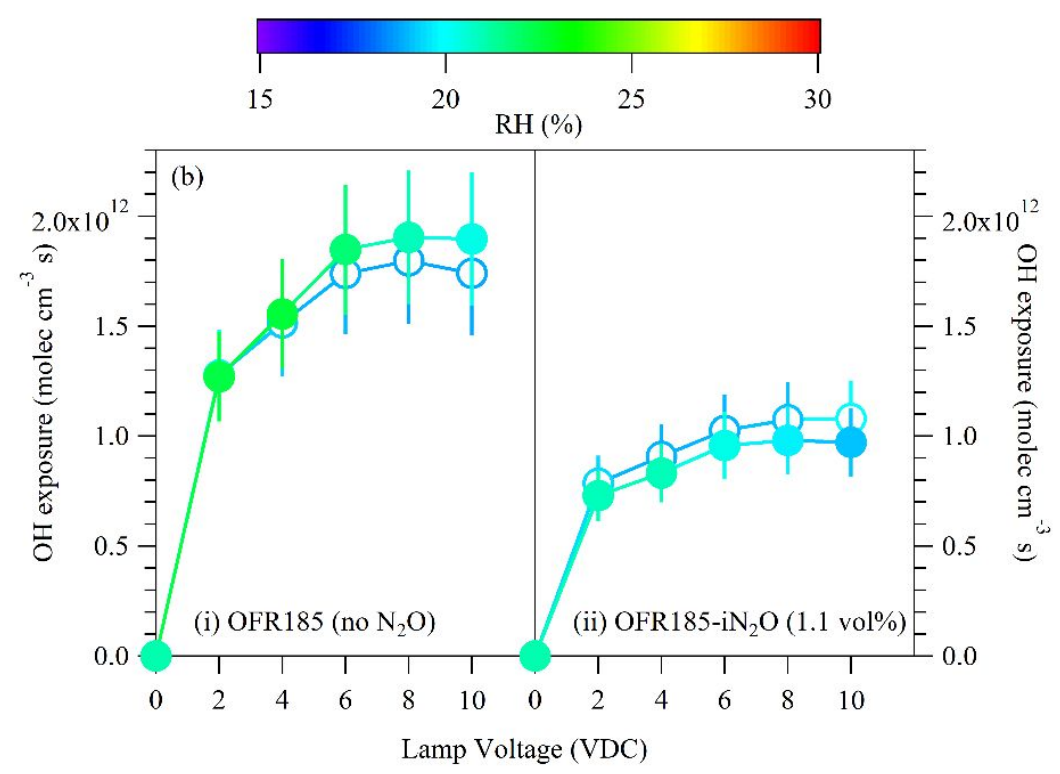

Figure S4. Off-line calibrations of the OFR using $\mathrm{SO}_{2}$ without (i) and with (ii) $\mathrm{N}_{2} \mathrm{O}$ injections. 


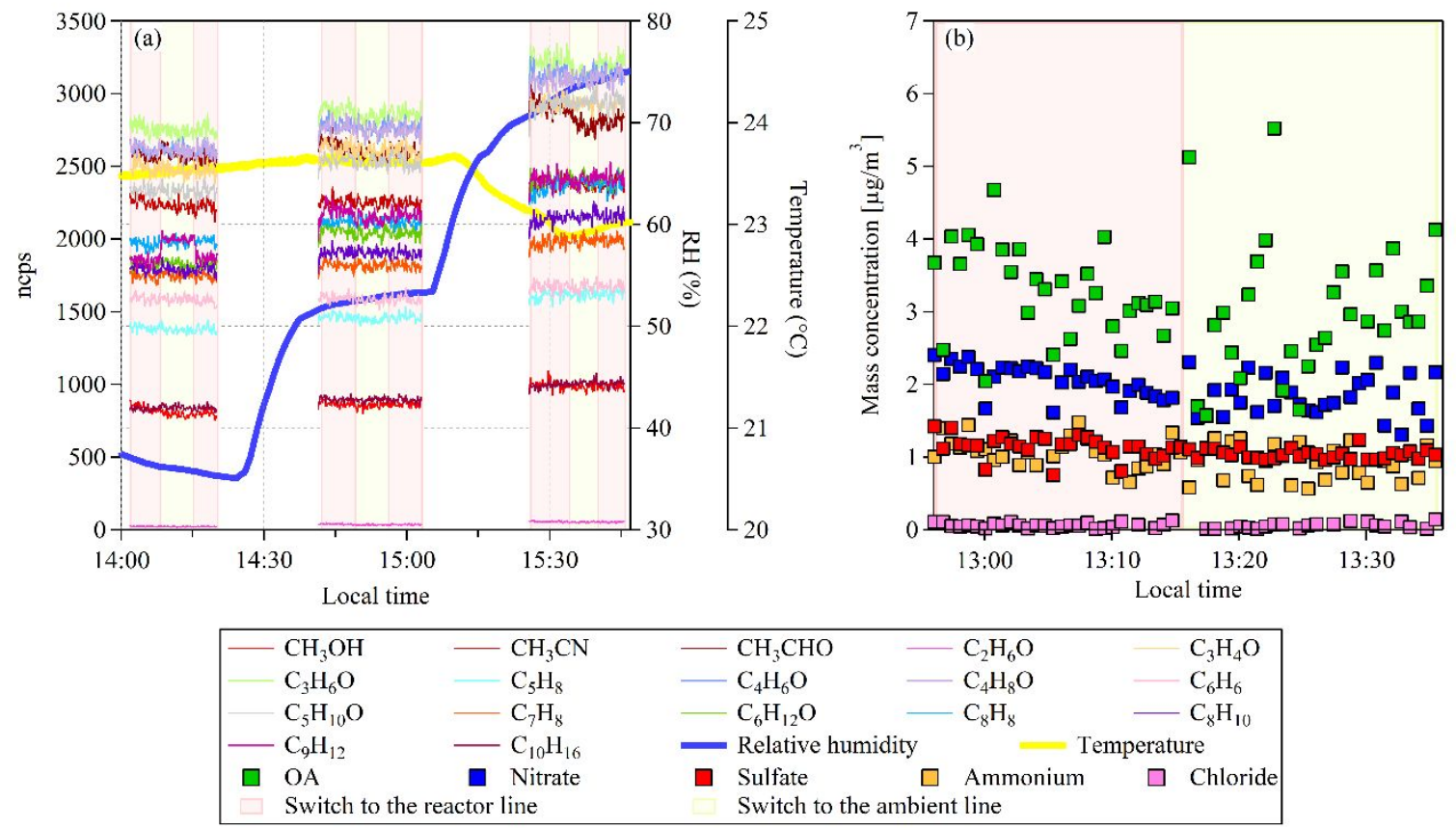

Figure S5. Signals of (a) VOCs and (b) $\mathrm{PM}_{2.5}$ components for the wall loss experiments. 


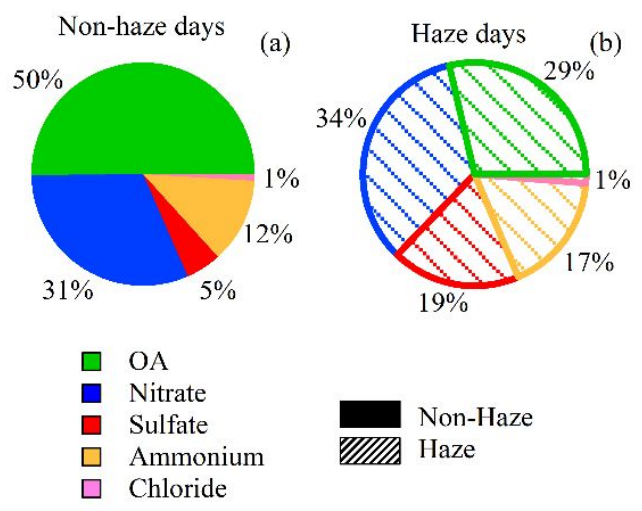

Figure S6. Chemical compositions of non-refractory $\mathrm{PM}_{2.5}$ measured by the TOF-ACSM during the (a) non-haze days and (b) haze days. 


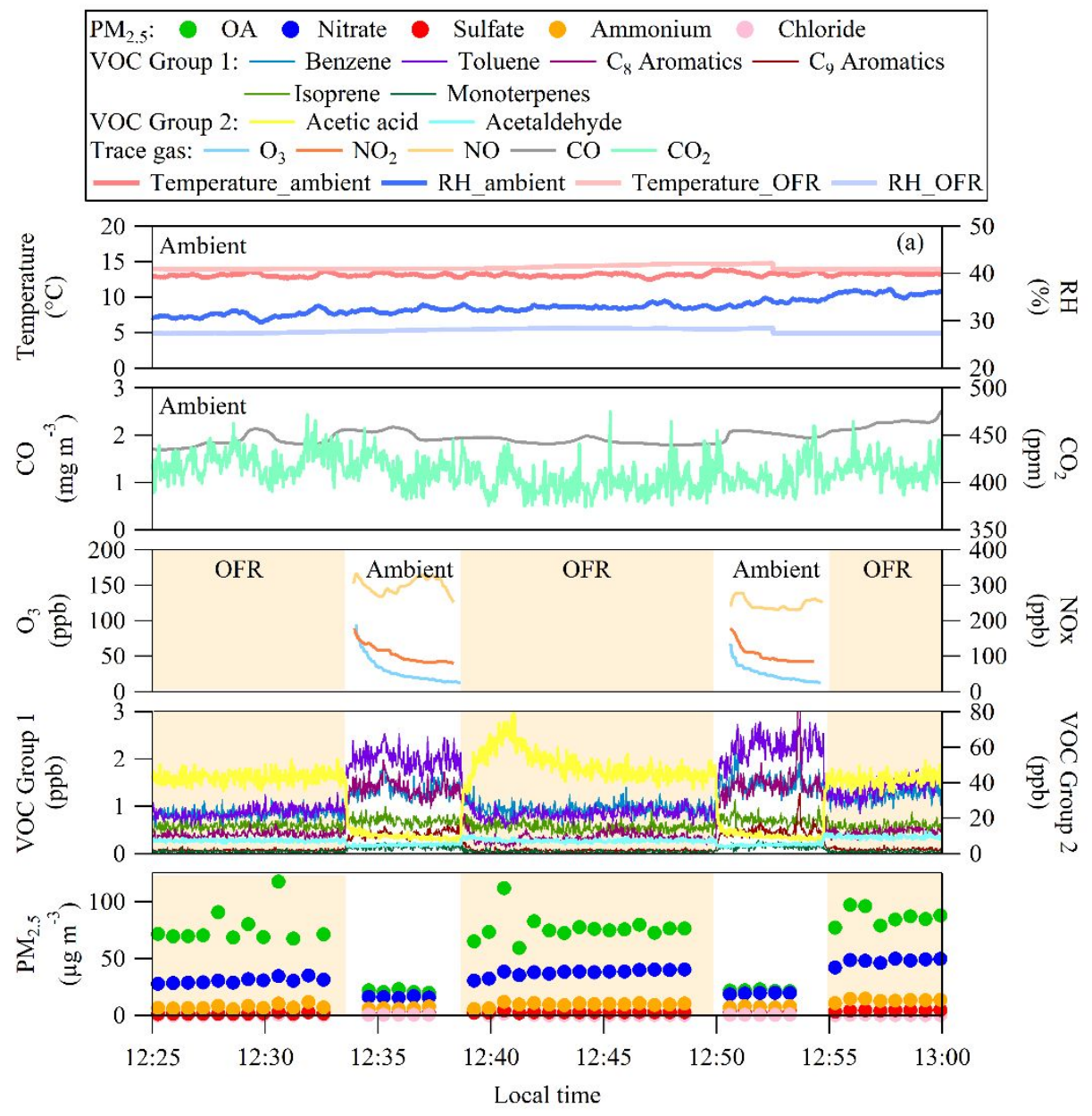

Figure S7. A typical concentration time series of particle composition, VOCs and other gaseous pollutants, relative humidity and temperature inside and outside the OFR in on-road OFR experiments (particle-corrected). The yellow-shaded periods represent the measurement of the reactor line when sample air was exposed to high concentration of $\mathrm{OH}$ radical. The non-shaded periods correspond to the ambient line when ambient pollutants were measured. 


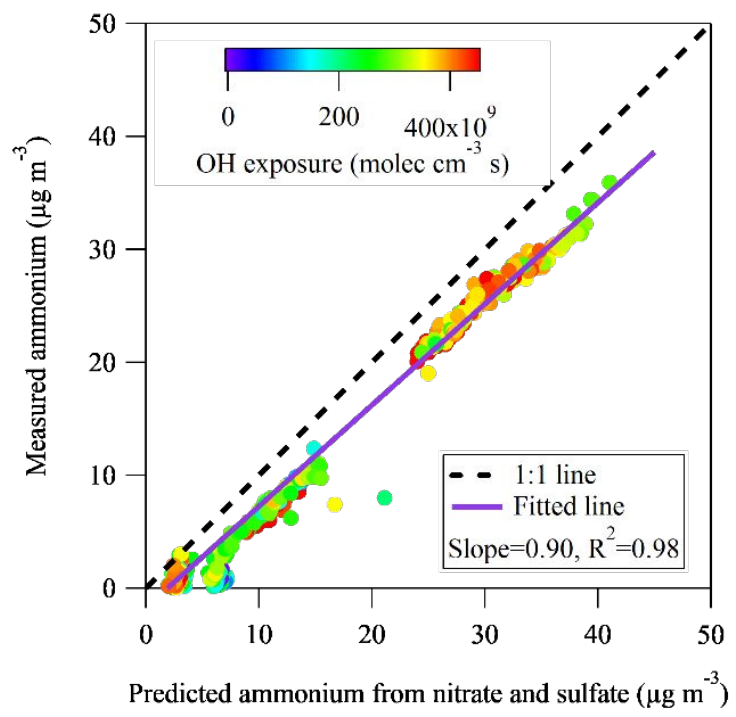

Figure S8. Ammonium balance in $\mathrm{PM}_{2.5}$ after exposed in the OFR. Slope and correlation coefficient $(R)$ are obtained from reduced major axis regression (implemented in the Lmodel2 in R studio software package). 

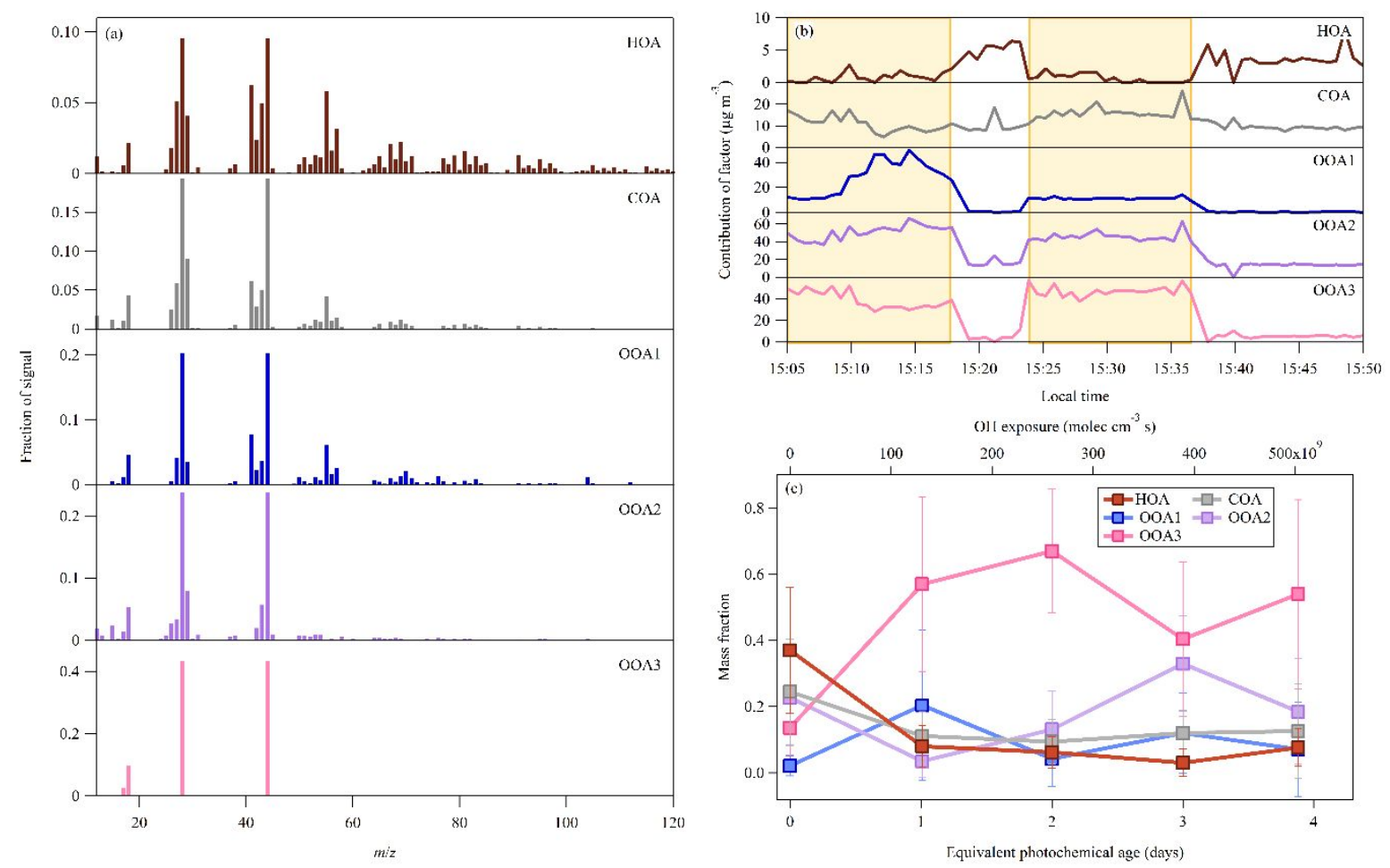

Figure S9. (a) Mass spectra of the OA factors identified by PMF. (b) Time series of mass concentrations of the OA factors for a typical OFR run. The yellow-shaded periods represent the measurement of the reactor line with high $\mathrm{OH}$ exposure and the non-shaded periods correspond to the ambient line. (c) Mass fractions of the $\mathrm{OA}$ factors as a function of $\mathrm{OH}$ exposure. 


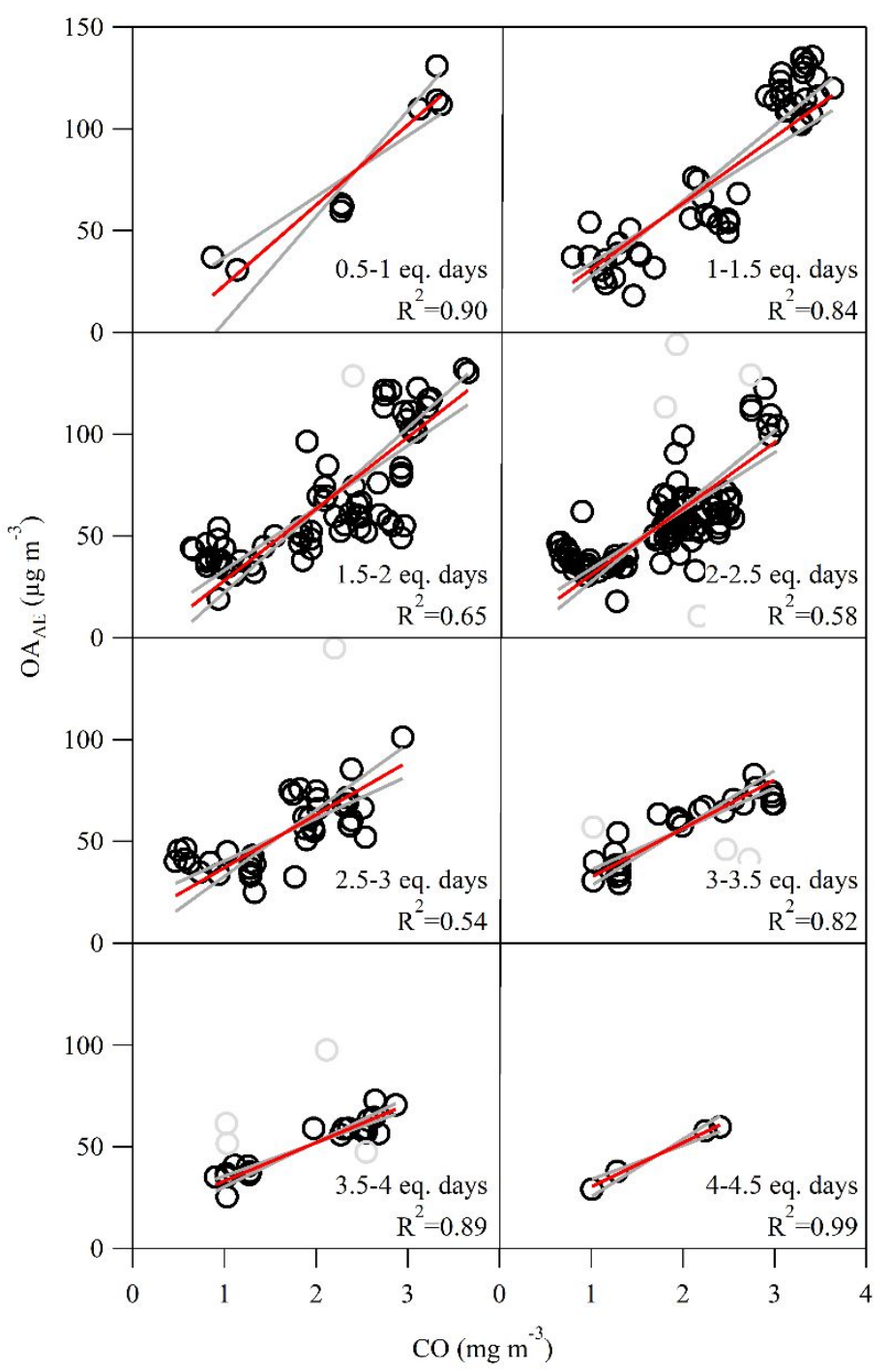

Figure S10. Scatter plots of OA enhancement versus CO. The circles are all individual data points (40 s on the basis of valid TOF-ACSM measurements) and the grey ones are outliers. The red lines represent the fits from the reduced major axis regression, implemented in the Lmodel2 in $\mathrm{R}$ studio software package, and the grey lines are the corresponding 95\% confidence intervals. The equivalent photochemical age intervals and $R^{2}$ are also shown. 


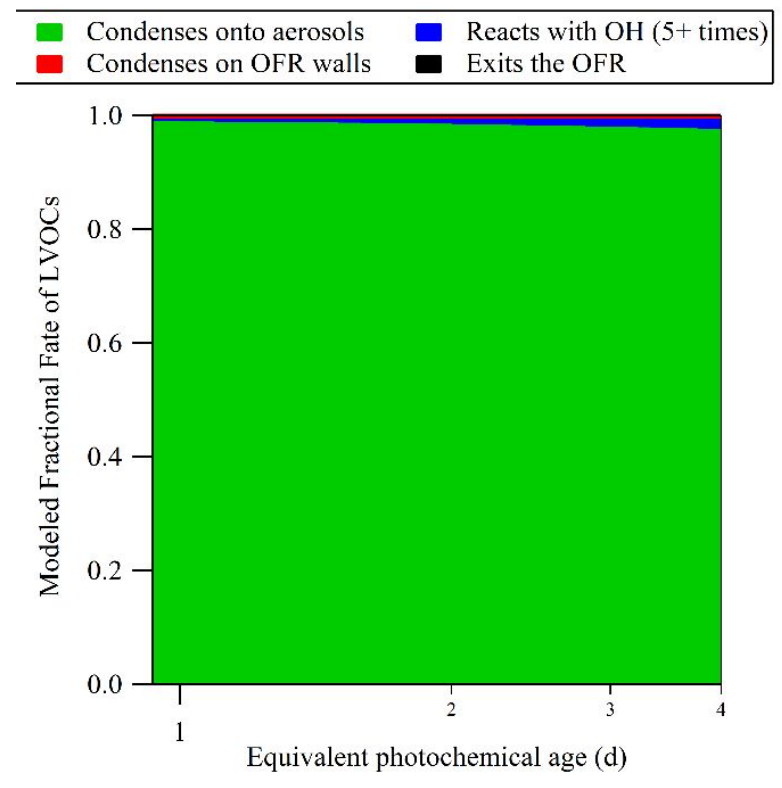

Figure S11. The average fractional fates of different LVOC pathways in the OFR for the study herein, estimated by the LVOC fate model that is introduced by Palm et al. ${ }^{10}$ 


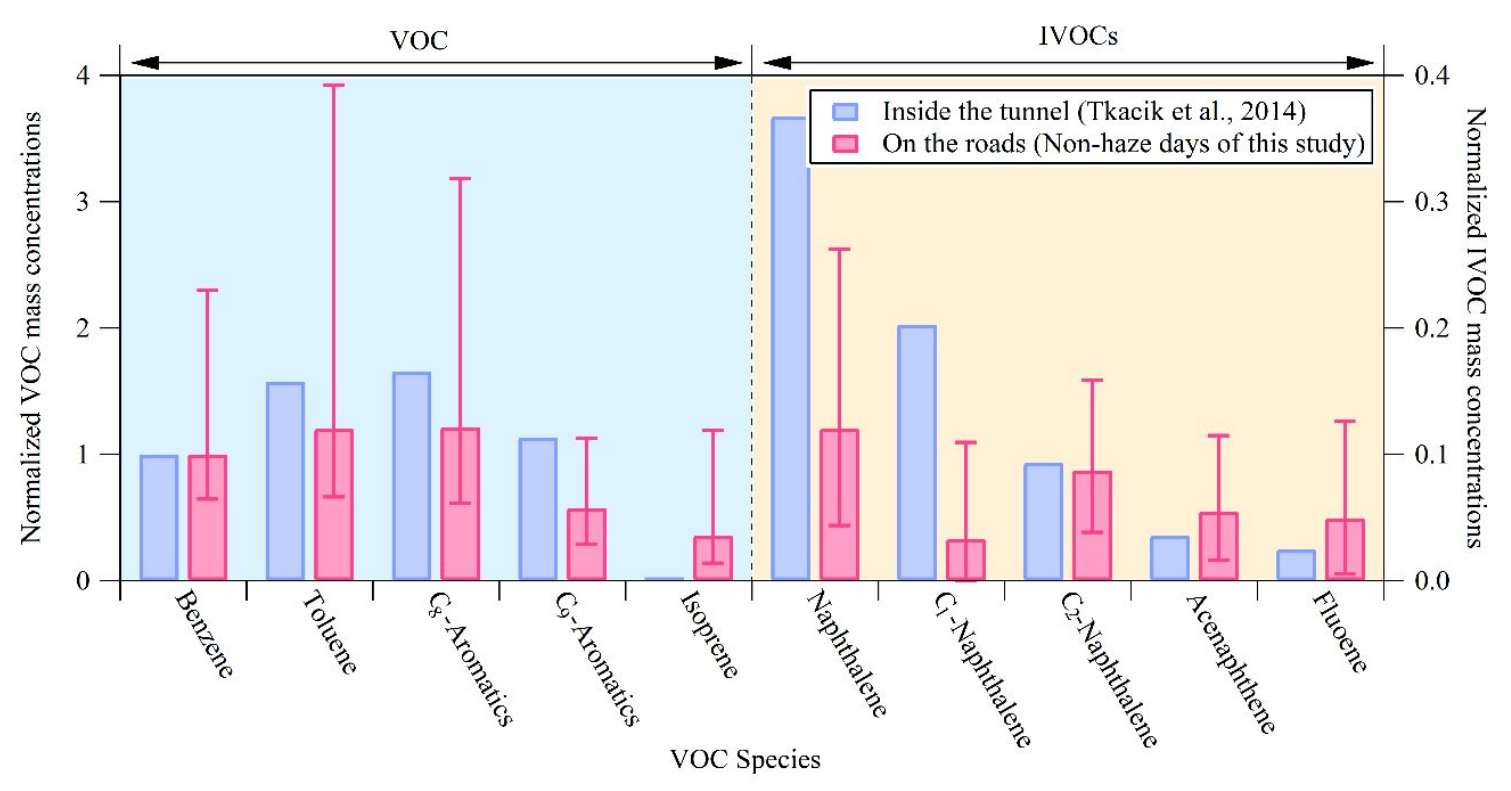

Figure S12. Medium VOC concentrations normalized to benzene concentrations measured in this study (on the roads) and in the Pittsburgh study (inside the tunnel). The error bars show the $75^{\text {th }}$ and $25^{\text {th }}$ percentiles. In the tunnel study, $\mathrm{C}_{8}$-aromatics represent the sum of ethylbenzenes and xylenes and $\mathrm{C}_{9}$-aromatics represent the sum of propylbenzenes, ethyltoluenes and trimethylbenzenes. 


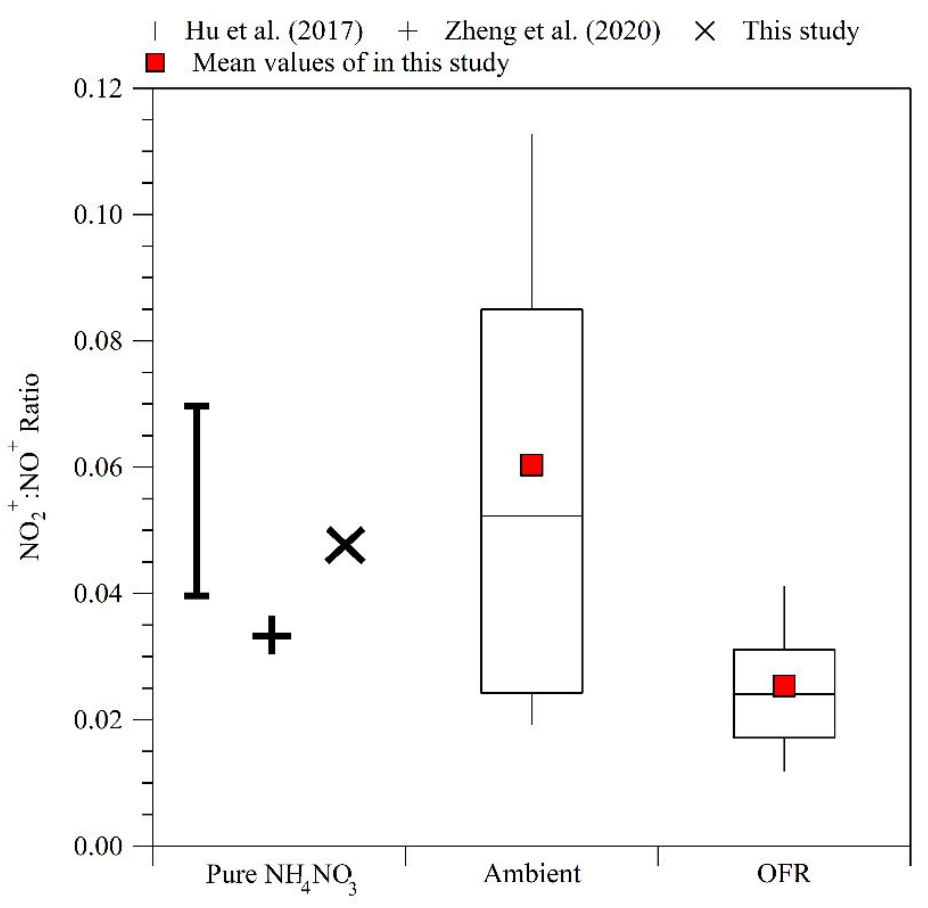

Figure S13. $\mathrm{NO}_{2}^{+}$: $\mathrm{NO}^{+}$ratios for pure $\mathrm{NH}_{4} \mathrm{NO}_{3},{ }^{4,33}$ on-road aerosols through the ambient line, and the reactor line with the equivalent photochemical age ranged from 1 to 3 days for a mean $\mathrm{OH}$ concentration of $1.5 \times 10^{6}$ molecules $\mathrm{cm}^{-3}$. 


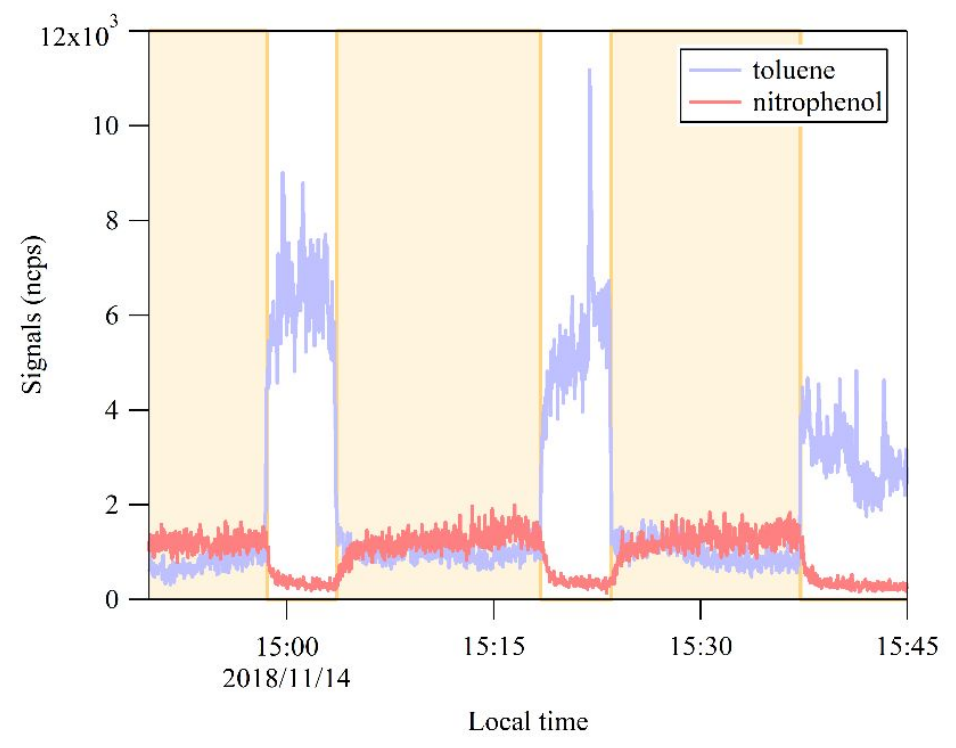

Figure S14. Time series of the signals of toluene and nitrophenol measured by PTR-QiTOF in a typical on-road OFR experiment. The yellow-shaded periods represent the measurement of the reactor line when sample air was exposed to high concentration of $\mathrm{OH}$ radicals. 

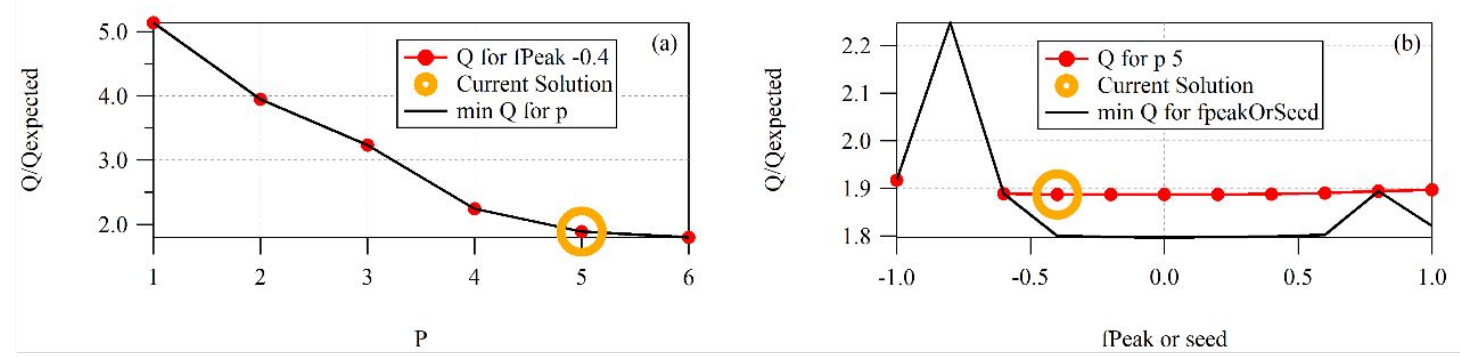

Figure S15. PMF diagnostics for $Q / Q_{\exp }$. 

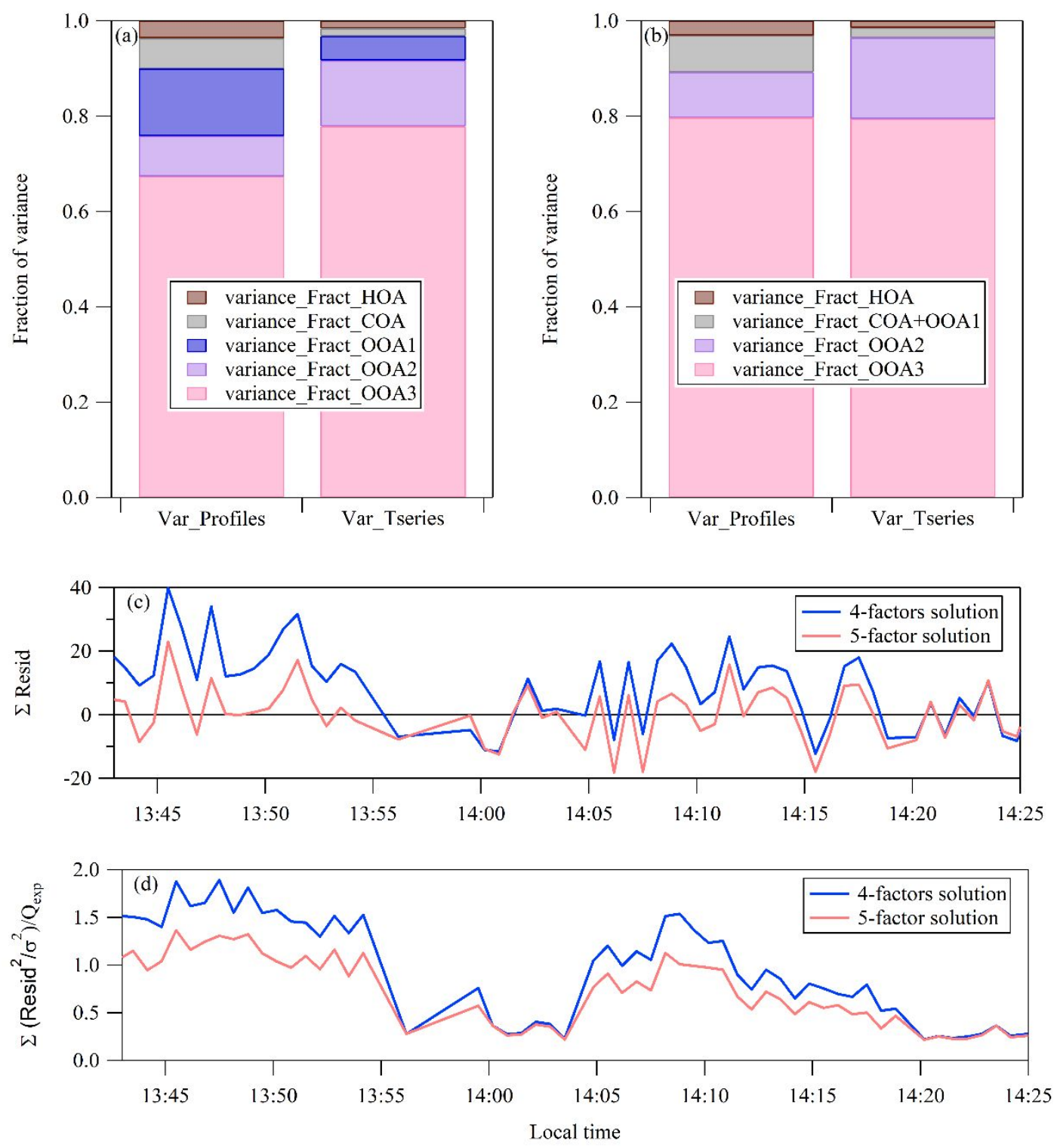

Figure S16. PMF diagnostics for variance and residuals. 


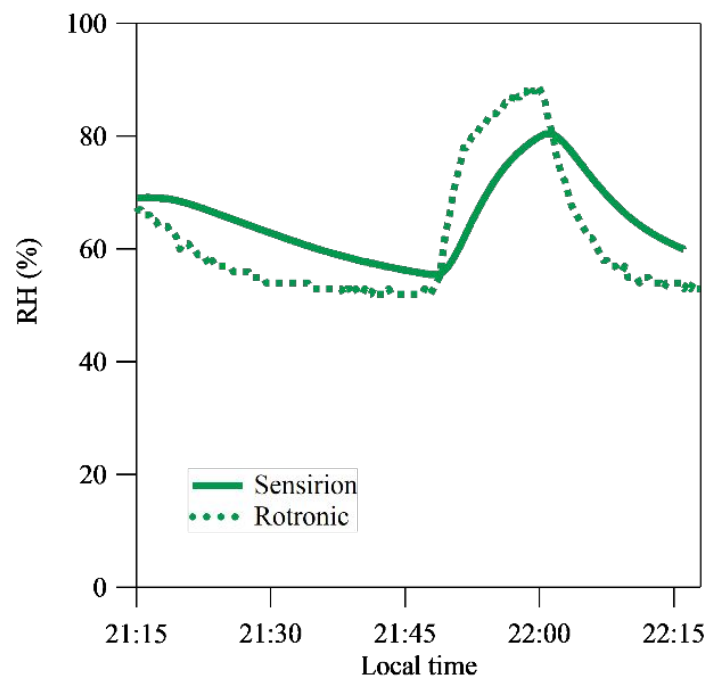

Figure S17. RH/T sensor test. 